\title{
American Journal of Diseases of Children
}

\author{
\begin{tabular}{lll}
\hline \hline Vol. 22 & DECEMBER, 1921 & No. 6 \\
\hline
\end{tabular} \\ BLOOD STUDIES IN THE NEW-BORN \\ MORPHOLOGICAL; CHEMICAL; COAGULATION ; UROBILIN \\ AND BILIRUBIN * \\ WILLIAM PALMER LUCAS, M.D.; \\ BRADFORD FRENCH DEARING, M.D.; HAL R. HOOBLER, M.D.; \\ ANITA COX; MARTHA R. JONES, PH.D., \\ AND \\ FRANCIS SCOTT SMYTH, M.A. \\ SAN FRANCISCO \\ INTRODUCTION
}

Reviewing the literature on blood studies one is struck by the comparatively few extensive investigations which have been carried on with the blood of the new-born. The morpohologic variations in hemoglobin and cells have received more consideration than any other phase of the problem. The chemistry of the blood of the new-born has been given little attention. Sedgwick's ${ }^{1}$ findings stand out as the most extensive and illuminating, and Slemon's ${ }^{2}$ investigations on maternal and fetal blood are fundamental, furnishing conclusive evidence of the mechanistic function of the placenta. Coagulation has been given little real attention and except for isolated studies on individual cases of hemorrhages of the new-born few, beside Rodda, ${ }^{3}$ have attempted to analyze the factors entering into this problem.

We have, therefore, attempted to bring together all these phasesmorphology, chemistry, coagulation and pigment metabolism-into a combined study of the blood of the normal new-born infant. All blood

\footnotetext{
* From the Hooper Foundation of Medical Research.

* This work was made possible in part by a grant from Mr. William $\mathrm{H}$. Crocker.

* From the Department of Pediatrics, University of California Medical School. This paper represents Series No. 6, Studies on Blood, which includes the following papers: 1. A Study of the Blood in Hemophilia, S. H. Hurwitz and W. P. Lucas. 2. Blood Volume in Infants Estimated by the Vita1 Dye Method, William Palmer Lucas and Bradford French Dearing. 3. Distribution of Calcium in Phosphoric Acid in the Blood of Normal Children, Martha R. Jones and Lillian L. Nye. 4. On the Etiology of Hemorrhagic Disease of the New-Born, Clain Fanning Gelston. 5. Physiology of the Blood in Infancy and Childhood, W. P. Lucas.

1. Sedgwick: Am. J. Dis. Child. 14:98 (Aug.) 1917; 19:429 (June) 1920.

2. Slemon: Bull. Johns Hopkins Hosp. 27:343 (Dec.) 1916; J. Biol. Chem. 32:63 (Oct.) 1917; Am. J. Obst. 80:194 (Aug.) 1919.
}

3. Rodda: Am. J. Dis. Child. 19:269 (Apri1) 1920. 
specimens were obtained from longitudinal sinus puncture, the blood being obtained at intervals from a few hours after birth to the fourteenth day post partem. In a few cases later specimens were obtained, if the child remained in the hospital for a longer period, but few of these findings are presented, except as they represent a continuation of a serial study on the identical baby. Most of our figures represent serial studies; i. e., blood obtained on alternate days from the same baby. In this way we have studied over one hundred and fifty babies. It would be impossible, of course, to make all the determinations we wished from the amount of blood we felt it safe to take from each baby, so that the numbers in the various series differ considerably, but in each case we think a sufficient number of examinations were made to show the variations that occur normally in the blood of the new-born infant.

\section{HEMOGLOBIN}

The estimation of hemoglobin by most of the clinical methods now in vogue, as has been pointed out frequently during the past few years, is very faulty and inaccurate, giving errors as high as 20 or 30 per cent. and in some instances as high as 50 per cent. as compared with the methods of estimating the hemoglobin by the oxygen capacity of the red blood cells either by the Palmer ${ }^{4}$ method or by the modification of this method as described by Robscheit. ${ }^{5}$ From clinical experience we have found this method (acid hematin) very satisfactory and reliable. Our tables for hemoglobin show the same high values found by most workers during the first few days with a decided drop during the second week. This bears out the estimations made by Williamson of the total hemoglobin in grams per hundred c.c. of blood.

Williamson ${ }^{6}$ has accurately determined the amount of hemoglobin in grams per hundred c.c. of blood in infants, children and adults. He found that on the first day there are $23.25 \mathrm{gm}$. ; for the second and third days, $22.78 \mathrm{gm}$.; fourth to eighth days, $22.12 \mathrm{gm}$.; ninth to thirteenth days, $21.35 \mathrm{gm}$. The decrease in hemoglobin continues to the first year and second year when it is 12.53 and 12.57 gm., respectively. From that time on it gradually increases till it reaches its fairly constant average between the sixteenth and twentieth years of $16.25 \mathrm{gm}$. hemoglobin per hundred c.c. of blood. There is a very decided drop from 21.35 to $18.42 \mathrm{gm}$. between the thirteenth day and the period from two weeks to two months. In the third to fifth months it drops to 13.66 gm. and from the sixth to the eleventh months it remains about the

4. Palmer: J. Biol. Chem. 41:209, 1920.

5. Robscheit: J. Biol. Chem. 41:209, 1920.

6. Williamson: Arch. Int. Med. 18:505 (Oct.) 1916. 
same, $13.70 \mathrm{gm}$. Williamson concludes that the amount of hemoglobin in the blood of normal persons varies greatly at different ages and follows a well defined curve. The variations are greatest from birth to sixteen years.

Our results on hemoglobin estimation are shown in Table. 1.

This average corresponds very closely with the average results of E. Schiff ${ }^{7}$ which were made at Prague and Budapest.

TABLE 1.-Results on Hemoglobin Estimation

\begin{tabular}{|c|c|c|c|c|}
\hline Days & Cases & Maximum & Average & Minimum \\
\hline 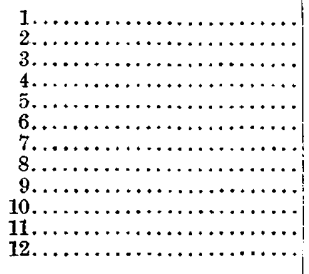 & $\begin{array}{l}36 \\
27 \\
17 \\
26 \\
18 \\
21 \\
16 \\
20 \\
17 \\
13 \\
18 \\
12\end{array}$ & $\begin{array}{l}140 \\
135 \\
135 \\
130 \\
125 \\
130 \\
125 \\
125 \\
115 \\
120 \\
120 \\
115\end{array}$ & $\begin{array}{r}117 \\
114 \\
110 \\
114 \\
107 \\
113 \\
109 \\
103 \\
103 \\
97 \\
98 \\
91\end{array}$ & $\begin{array}{r}85 \\
100 \\
80 \\
95 \\
75 \\
80 \\
75 \\
60 \\
90 \\
70 \\
70 \\
55\end{array}$ \\
\hline
\end{tabular}

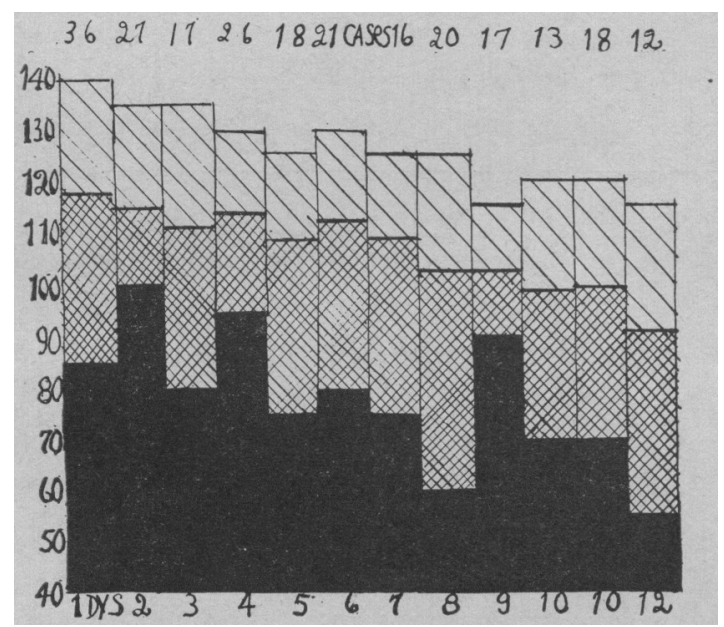

Fig. 1.- Hemoglobin from sinus blood.

Williamson ${ }^{8}$ reports his studies on grams of hemoglobin per hundred c.c. of blood. His average finding on the first day was $23.25 \mathrm{gm}$., this gradually decreasing in amount until the age of two years was reached (12.57 $\mathrm{gm}$.). From this age to fifteen years there was a gradual increase to $14.69 \mathrm{gm}$. Our findings on the hemoglobin per cent. in the first few weeks of life show a curve parallel to his curve.

7. Schiff, E.; von Reuss, August Ritter: The Diseases of the New-Born, New York, William Wood \& Co., 1921.

8. Williamson: Arch. Int. Med. 18:521 (Oct.) 1916. 
Hiemann ${ }^{9}$ states that the hemoglobin of jaundiced infants is distinctly lower than that of normal infants. We have not been able to demonstrate this as the hemoglobin in some of our most markedly jaundiced infants was just as high as in infants without jaundice. As we shall show, bile pigment is present in nearly all new-born infants even though they are clinically free from icterus. As our estimates were made from blood obtained from the longitudinal sinus, we compared these findings with a series in which the blood was taken from puncture in the usual way. Our tables show slight variations, the sinus hemoglobin tending to be higher (Tables 2, 3 and 4).

Table 2.-Hemoglobin of Sinus and Peripheral Blood Compared

\begin{tabular}{|c|c|c|c|c|}
\hline Days & Cases & Maximum & Average & Minimum \\
\hline 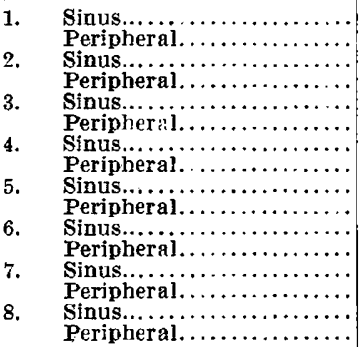 & $\begin{array}{r}16 \\
13 \\
16 \\
9 \\
7 \\
8 \\
17 \\
8 \\
9 \\
7 \\
18 \\
6 \\
11 \\
5 \\
11 \\
4\end{array}$ & $\begin{array}{l}140 \\
145 \\
135 \\
122 \\
125 \\
130 \\
130 \\
125 \\
125 \\
118 \\
130 \\
110 \\
125 \\
108 \\
125 \\
100\end{array}$ & $\begin{array}{r}124 \\
130 \\
122 \\
118 \\
114 \\
115 \\
119 \\
111 \\
112 \\
109 \\
108 \\
103 \\
115 \\
101 \\
108 \\
94\end{array}$ & $\begin{array}{r}110 \\
120 \\
105 \\
110 \\
100 \\
98 \\
108 \\
98 \\
100 \\
100 \\
90 \\
94 \\
95 \\
95 \\
100 \\
95\end{array}$ \\
\hline
\end{tabular}

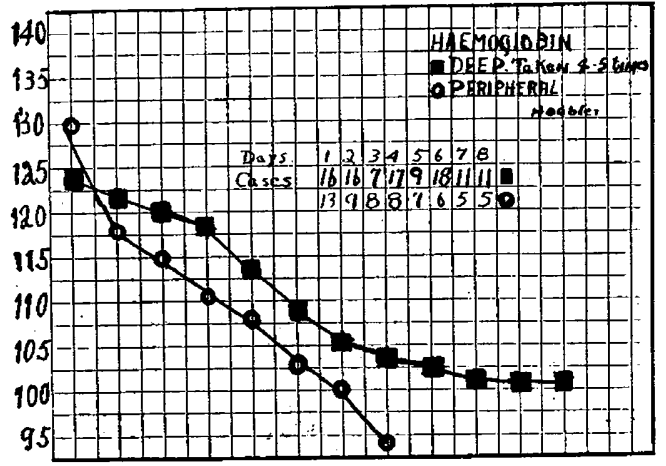

Fig. 2.-Comparing hemoglobin from sinus blood and peripheral blood.

\section{RED BLOOD CELLS}

The red blood cell counts are high during the first week and then gradually decrease, corresponding very closely with the hemoglobin estimations (Tables 3 and 4).

9. Hiemann: Zur Lehre des Ikterus Neonatorum, Ztschr. f. Geb. u. Gyn. $49: 165,1911$. 
As is shown in the tables, the variations between the lowest counts and the highest are quite marked and correspond very well with the variations between the highest and lowest percentage of hemoglobin. The difference between the sinus and peripheral counts is slightly in

TABle 3.-Red Bloon Cell Counts for Twelve Days

\begin{tabular}{|c|c|c|c|c|}
\hline Days & Cases & Maximum & Average & Minimum \\
\hline 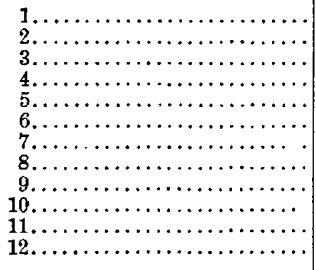 & $\begin{array}{l}31 \\
26 \\
17 \\
25 \\
15 \\
20 \\
16 \\
19 \\
20 \\
13 \\
18 \\
12\end{array}$ & $\begin{array}{l}6,700,000 \\
6,200,000 \\
7,800,000 \\
6,200,000 \\
6,700,000 \\
6,600,000 \\
6,000,000 \\
5,600,000 \\
5,700,000 \\
5,500,000 \\
5,700,000 \\
5,800,000\end{array}$ & $\begin{array}{l}5,511,000 \\
5,352,000 \\
5,116,000 \\
5,244,000 \\
4,983,000 \\
5,114,000 \\
5,108,000 \\
4,504,000 \\
4,891,000 \\
4,130,000 \\
4,561,000 \\
4,533,000\end{array}$ & $\begin{array}{l}4,000,000 \\
4,100,000 \\
3,500,000 \\
4,000,000 \\
3,800,000 \\
2,000,000 \\
3,800,000 \\
3,800,000 \\
3,800,000 \\
2,800,000 \\
3,500,000 \\
2,000,000\end{array}$ \\
\hline
\end{tabular}

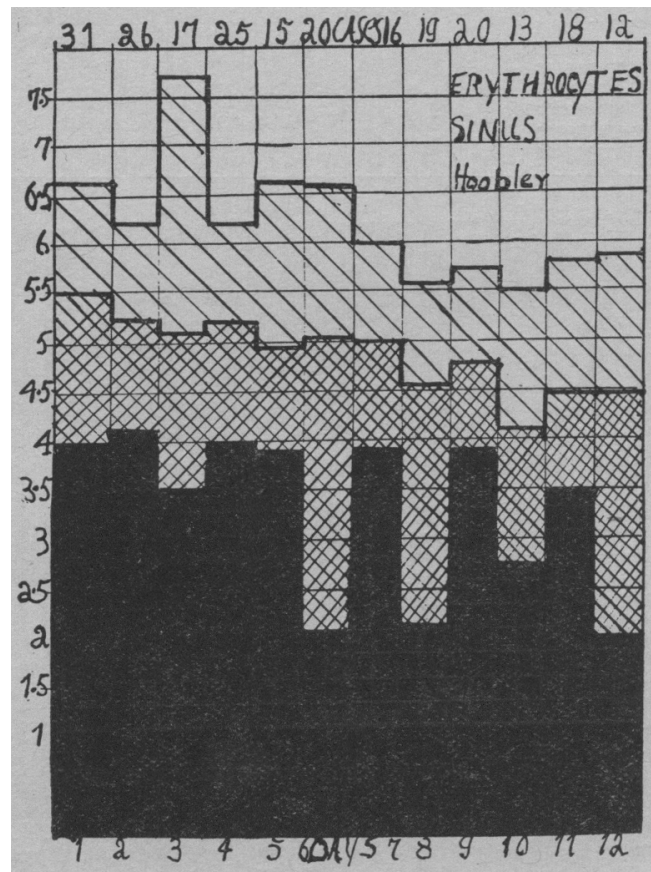

Fig. 3.-Red blood cells from sinus.

favor of the sinus counts, though this is not striking but it is interesting as it corresponds with the hemoglobin findings. Such variations in peripheral and deep circulation may depend on a number of different factors, as rate of circulation, volume, temperature, oxygen needs and exchange, etc. 
Hiemann found values lower in icteric babies than in those free from icterus-5,500,000 as compared with $6,500,000$. This we were unable to substantiate.

Much discussion has taken place on the values of the hemoglobin and red blood cells depending upon whether the cord is tied immediately or late, i.e., when pulsation ceases in the maternal half of the cord. According to Schiff, when the cord is ligated late the red blood cells rise between the second and fourth days, but when it is tied early the

TABle 4.--Red Blood Cells of Sinus and Peripheral Blood

\begin{tabular}{|c|c|c|c|c|c|}
\hline \multicolumn{2}{|r|}{ Days } & Cases & Maximum & Average & Minimum \\
\hline $\begin{array}{l}1 . \\
2 . \\
3 . \\
4 . \\
5 .\end{array}$ & 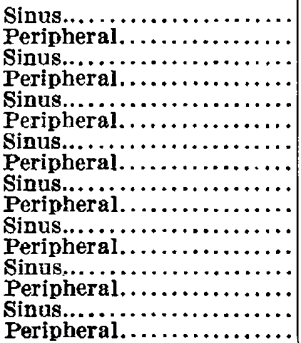 & $\begin{array}{r}16 \\
12 \\
15 \\
9 \\
7 \\
8 \\
17 \\
7 \\
9 \\
7 \\
16 \\
6 \\
10 \\
5 \\
11 \\
5\end{array}$ & $\begin{array}{l}6,806,000 \\
7,024,000 \\
5,952.000 \\
5,892,000 \\
5,645,000 \\
7,000,000 \\
6,108,000 \\
5,720,000 \\
6,016,000 \\
5,072,000 \\
6,624,000 \\
5,820,000 \\
6,080,000 \\
4,950,000 \\
5,248,000 \\
5,616,000\end{array}$ & $\begin{array}{l}5,650,000 \\
6,080,000 \\
5,295,000 \\
5,430,000 \\
5,426,000 \\
5,238,000 \\
5,268,000 \\
5,180,000 \\
5,082,000 \\
4,962,000 \\
5,053,000 \\
4,720,000 \\
5,119,000 \\
4,900,000 \\
4,800,000 \\
4,702,000\end{array}$ & $\begin{array}{l}4,760,000 \\
5,336,000 \\
4,192,000 \\
4,900,000 \\
4,510,000 \\
4,432,000 \\
4,162,000 \\
4,656,000 \\
4,120,000 \\
4,464,000 \\
3,936,000 \\
4,500,000 \\
3,924,000 \\
4,550,000 \\
4,320,000 \\
4,216,000\end{array}$ \\
\hline
\end{tabular}

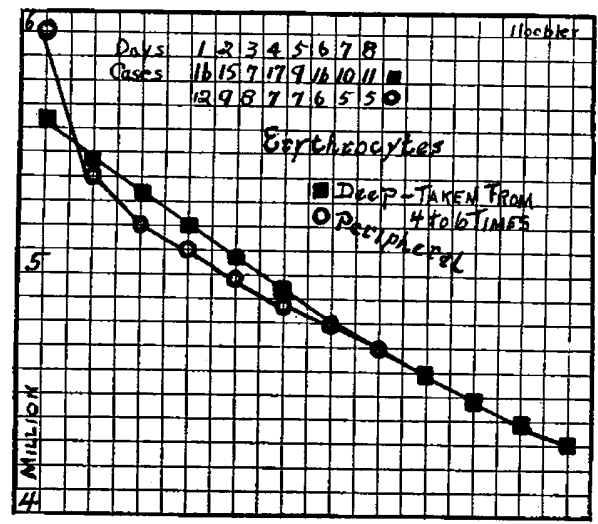

Fig. 4.-Comparison of red blood cells from sinus and peripheral circulation.

fall begins immediately. As all our cases had their cords tied late, i.e., when the pulsation stopped in the middle of the cord, it can be seen from our figures that the red blood cells have no definite tendency to rise between the second and fourth days, as claimed by Schiff.

There are certain definite things to be observed about the red blood cells of the new-born:

1. We found nucleated cells in 52 per cent. of all cases on the first day ( 1 per cent. of differential count) and in only 5 per cent. on the second day ( 0.5 per cent. of differential count). 
2. Variation in size is more marked in the early days, larger and smaller cells both being more numerous (showing disturbance in equilibrium of the red blood cell producing organs).

table 5.-White Cells from Sinus Blood

\begin{tabular}{|c|c|c|c|c|}
\hline Days & Cases & Maximum & Average & Minimum \\
\hline 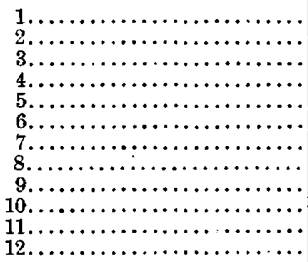 & $\begin{array}{l}31 \\
22 \\
16 \\
25 \\
17 \\
19 \\
16 \\
21 \\
20 \\
12 \\
18 \\
12\end{array}$ & $\begin{array}{l}30,000 \\
38,000 \\
20,000 \\
19,000 \\
14,000 \\
17,000 \\
21,000 \\
45,000 \\
23,000 \\
18,800 \\
17,400 \\
22,200\end{array}$ & $\begin{array}{l}19,200 \\
15,300 \\
11,100 \\
10,300 \\
10,900 \\
11,500 \\
12,100 \\
12,400 \\
12,600 \\
12,200 \\
12,700 \\
13,200\end{array}$ & $\begin{array}{l}6,400 \\
8,400 \\
7,200 \\
6,400 \\
4,600 \\
7,400 \\
7,400 \\
6,400 \\
6,200 \\
7,600 \\
6,500 \\
7,000\end{array}$ \\
\hline
\end{tabular}

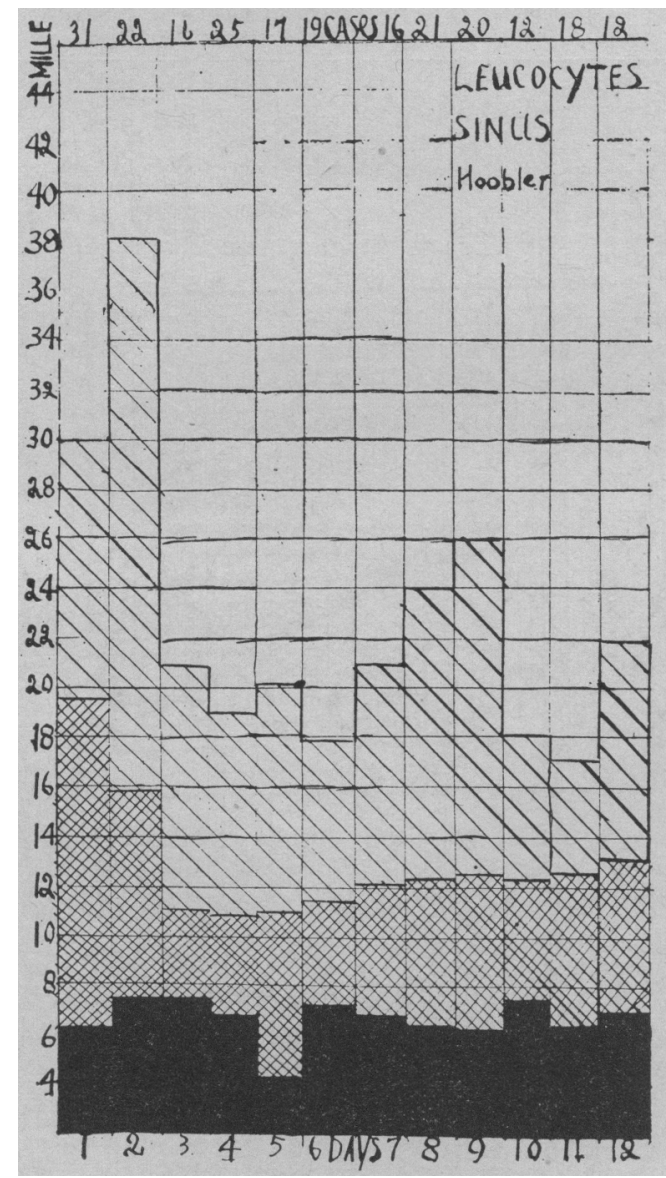

Fig. 5.-White blood count from sinus blood. 
3. Hemolysis occurs more easily; the cell membrane is more fragile so that "ghosts" are more frequent, the red blood cells apparently losing their hemoglobin easily though they have more stroma. Fine basophilic granules are more frequent during the first day or two; after that they are rare.

\section{WHITE BLOOD CELLS}

We observed the same leukocytosis in the new-born as has been noted by various authors, though this leukoctytosis is by no means constant. The results are shown in Table 5, giving our maximum, average and minimum counts.

TABLE 6.-Differential Sinus Counts

\begin{tabular}{|c|c|c|c|c|c|}
\hline Days & Cases & $\begin{array}{c}\text { Neutro- } \\
\text { phils }\end{array}$ & $\begin{array}{l}\text { Small } \\
\text { Lmypho- } \\
\text { cytes }\end{array}$ & $\begin{array}{l}\text { Transi- } \\
\text { tionals } \\
\text { and } \\
\text { Mono- } \\
\text { nuclears }\end{array}$ & $\begin{array}{c}\text { Eosino- } \\
\text { phils }\end{array}$ \\
\hline 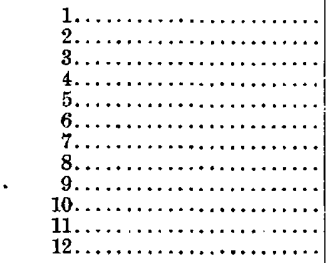 & $\begin{array}{l}32 \\
26 \\
16 \\
23 \\
20 \\
23 \\
16 \\
20 \\
19 \\
14 \\
17 \\
12\end{array}$ & $\begin{array}{l}70 \\
62 \\
58 \\
54 \\
49 \\
45 \\
42 \\
37 \\
36 \\
35 \\
33 \\
30\end{array}$ & $\begin{array}{l}20 \\
24 \\
27 \\
30 \\
34 \\
37 \\
42 \\
45 \\
45 \\
46 \\
47 \\
48\end{array}$ & $\begin{array}{l}9 \\
11 \\
12 \\
13 \\
15 \\
16 \\
16 \\
16 \\
16 \\
15 \\
16 \\
14\end{array}$ & $\begin{array}{l}1 \\
1 \\
1 \\
11 / 2 \\
3 \\
4 \\
5 \\
4 \\
4 \\
2 \\
2 \\
2\end{array}$ \\
\hline
\end{tabular}

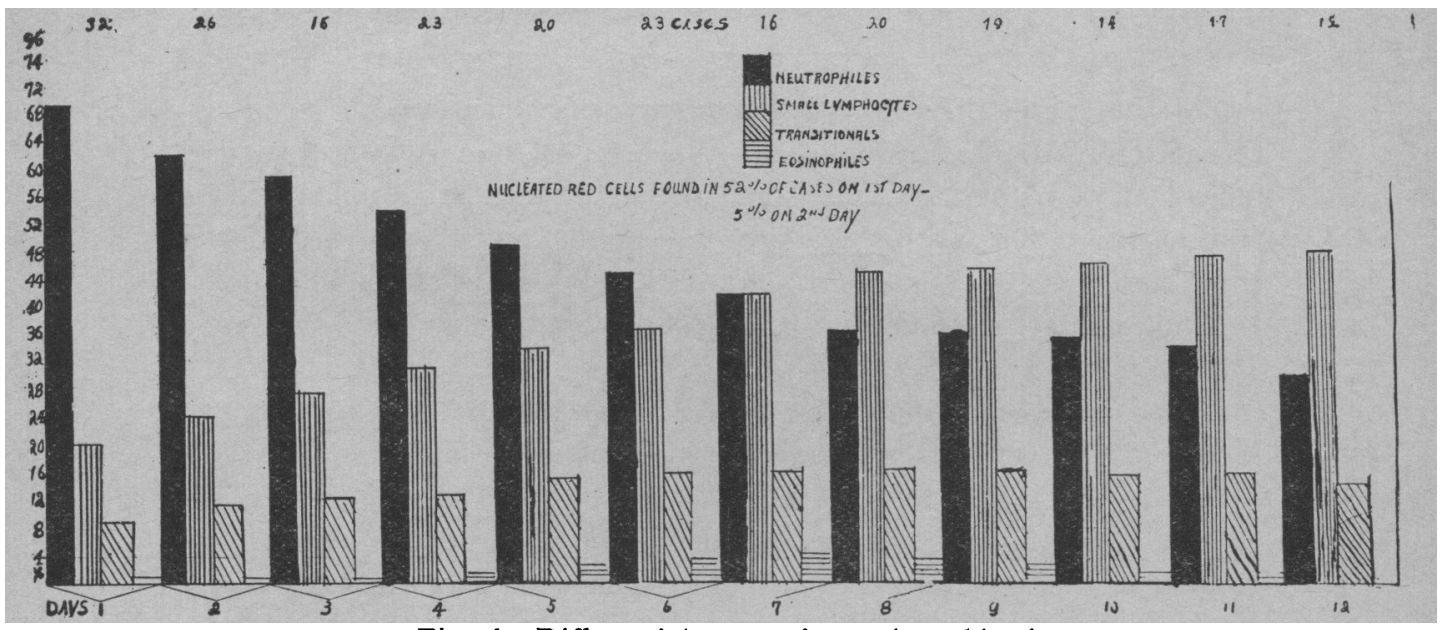

Fig. 6.-Differential count from sinus blood.

These counts correspond with those reported by von Reuss. ${ }^{10}$ Although the table of Scibiades is somewhat lower than our findings, the general curve corresponds very closely. Gundobin reports similar findings in early infancy.

10. Von Reuss: The Diseases of the New-Born, p. 41. 
The leukocytosis during the first week is definitely due to the polymorphonuclear cells. This continues to be so until the seventh day during which time the polymorphonuclears gradually decline, reaching the same level as the lymphocytes on this day. The lymphocytes during this same period gradually increase and are still increasing at the close of the period of our observation. There is slight increase in the transitional cells which toward the end of our period of observation decrease slightly. The same is true of the eosinophils. These findings are shown in Table 6.

We also compared the total counts between the sinus blood and the blood derived from the periphery. This latter again shows a slight increase over the count from the sinus blood (Table 7).

Table 7.-White Count of Sinus and Peripheral Blood Compared

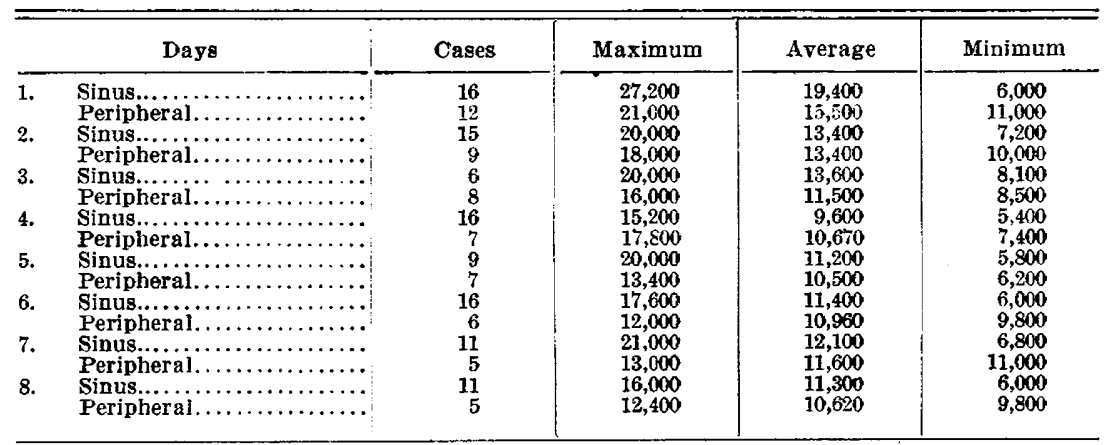

At the present time there is a great deal of discussion as to the classification of the various cells. We are just undertaking a careful investigation of these by using some of the newer vital staining methods and hope to report on this at a later date so that at this time we will not enter into the discussion of the various types of cells found.

Our platelet counts during the first eight days are shown in Table 8.

These figures correspond very nearly to those reported by Dr. Mary E. Morse. ${ }^{11}$ Morse found immediately after birth a platelet count which varied from 412,000 to 100,000 . We did not find any counts as low as the latter figure, our lowest being 196,000 on the eighth day. Neither were the platelets reduced in cases in which the coagulation was prolonged, nor was there any difference in cases that were markedly jaundiced or those that were slightly or not at all jaundiced. Rebaudi ${ }^{12}$ found a very much lower count, 95,000, in the new-born. The

11. Morse: The Blood Platelets in Normal Women, in Obstetrical Patients and in the New-Born, Boston M. \& S. J. 166:448, 1912.

12. Rebaudi: Von Reuss, p. 43. 


\section{AMERICAN JOURNAL OF DISEASES OF CHILDREN}

importance of platelet counts will be referred to in the discussion on coagulation.

\section{CHEMISTRY}

As pointed out by Sedgwick there are comparatively few studies on the chemistry of the blood of the new-born. For this reason we have repeated estimations on non-protein nitrogen, urea, uric acid, creatinin,

TABle 8.-Platelet Counts

\begin{tabular}{|c|c|c|c|c|}
\hline Days & Cases & Maximum & Average & Minimum \\
\hline 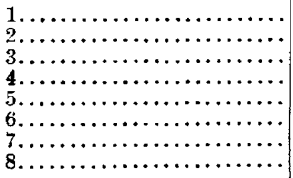 & $\begin{array}{r}12 \\
9 \\
8 \\
6 \\
7 \\
6 \\
5 \\
5\end{array}$ & $\begin{array}{l}396,000 \\
350,000 \\
380,000 \\
436,000 \\
330,000 \\
318,000 \\
318,000 \\
345,000\end{array}$ & $\begin{array}{l}305,000 \\
300,000 \\
308,000 \\
310,000 \\
295,000 \\
278,000 \\
278,000 \\
266,000\end{array}$ & $\begin{array}{l}225,000 \\
270,000 \\
204,000 \\
275,000 \\
220,000 \\
244,000 \\
250,000 \\
196,000\end{array}$ \\
\hline
\end{tabular}

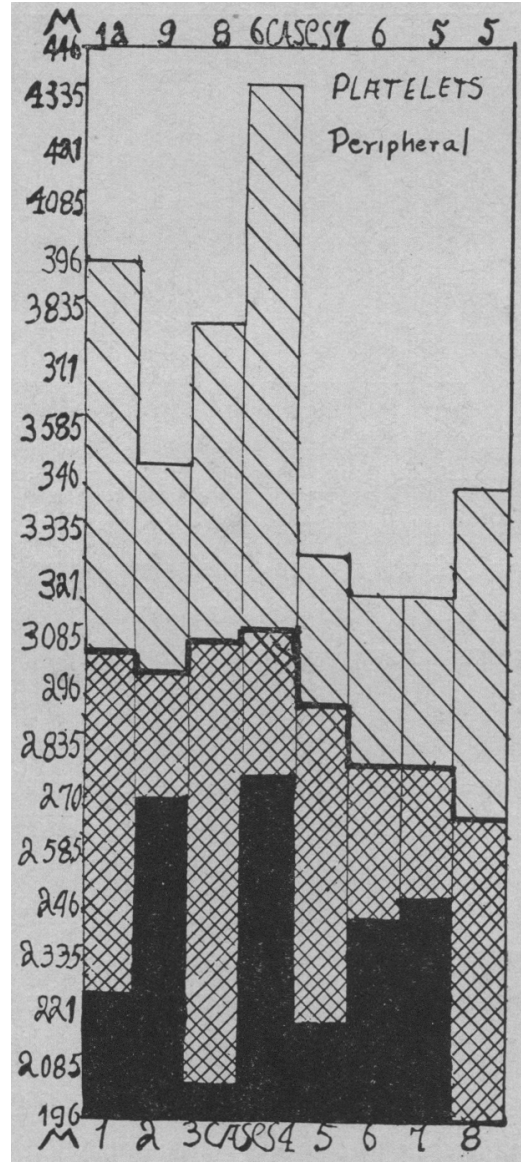

Fig. 7.-Platelet count from peripheral blood. 
sugar and carbon dioxid. We have been unable to find any values on the carbon dioxid made on blood of the new-born. Slemons has very clearly demonstrated that the placenta acts as a semipermeable membrane for most of the constituents of the blood so that the estimations of the maternal and fetal blood are approximately the same at the time of birth.

Table 9 gives our findings for the first twelve days.

TABLE 9.-Chemistry OF BloOd OF NeW-BorN

\begin{tabular}{|c|c|c|c|c|c|c|c|}
\hline & Day & $\begin{array}{c}\text { Nonprotein } \\
\text { Nitrogen, } \\
\text { Mg. per } \\
\text { 100 C.c. }\end{array}$ & $\begin{array}{c}\text { Urea } \\
\text { Nitrogen, } \\
\text { Mg. per } \\
100 \text { C.c. }\end{array}$ & $\begin{array}{c}\text { Urie } \\
\text { Acid, } \\
\text { Mg. per } \\
100 \text { C.c. }\end{array}$ & $\begin{array}{l}\text { Creat- } \\
\text { inin, } \\
\text { Mg. per } \\
\text { 100 C.c. }\end{array}$ & $\begin{array}{c}\text { Sugar, } \\
\text { per Cent. } \\
\text { per } \\
100 \text { C.c. }\end{array}$ & $\begin{array}{l}\text { Carbon } \\
\text { Dioxid, } \\
\text { vol. \% per } \\
100 \text { C.e. }\end{array}$ \\
\hline 0. & 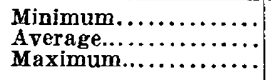 & $\begin{array}{l}32 \\
35 \\
40\end{array}$ & $\begin{array}{l}16 \\
18 \\
20\end{array}$ & $\begin{array}{l}2.07 \\
3.18 \\
4.54\end{array}$ & $\begin{array}{l}1.35 \\
1.41 \\
1.49\end{array}$ & $\begin{array}{l}0.043 \\
0.052 \\
0.062\end{array}$ & $\begin{array}{l}38.5 \\
52.5 \\
63.3\end{array}$ \\
\hline 1. & $\begin{array}{l}\text { Minimum.............. } \\
\text { Average.................. } \\
\text { Maximum............ }\end{array}$ & $\begin{array}{l}34 \\
40.6 \\
52\end{array}$ & $\begin{array}{l}17 \\
20.4 \\
26\end{array}$ & $\begin{array}{l}2.12 \\
3.27 \\
4.87\end{array}$ & $\begin{array}{l}1.48 \\
1.72 \\
2.00\end{array}$ & $\begin{array}{l}0.054 \\
0.066 \\
0.081\end{array}$ & $\begin{array}{l}38.5 \\
55.7 \\
64.3\end{array}$ \\
\hline 2. & 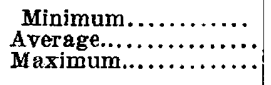 & $\begin{array}{l}28 \\
32.7 \\
36\end{array}$ & $\begin{array}{l}1 \dot{14} \\
16.3 \\
18\end{array}$ & $\begin{array}{l}1.40 \\
2.46 \\
3.42\end{array}$ & $\begin{array}{l}1.34 \\
1.54 \\
1.69\end{array}$ & $\begin{array}{l}0.045 \\
0.051 \\
0.060\end{array}$ & $\begin{array}{l}53.8 \\
63.4 \\
69.2\end{array}$ \\
\hline 3. & 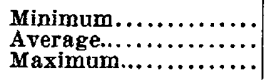 & $\begin{array}{l}30 \\
32.7 \\
36\end{array}$ & $\begin{array}{l}15 \\
16.3 \\
18\end{array}$ & $\begin{array}{l}2.08 \\
3.06 \\
5.00\end{array}$ & $\begin{array}{l}1.23 \\
1.42 \\
1.64\end{array}$ & $\begin{array}{l}0.055 \\
0.068 \\
0.075\end{array}$ & $\begin{array}{l}51.9 \\
55.7 \\
62.4\end{array}$ \\
\hline 4. & 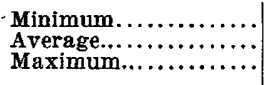 & $\begin{array}{l}26 \\
35.5 \\
53.1\end{array}$ & $\begin{array}{l}13 \\
17.5 \\
24\end{array}$ & $\begin{array}{l}1.47 \\
2.59 \\
4.00\end{array}$ & $\begin{array}{l}1.24 \\
1.49 \\
2.07\end{array}$ & $\begin{array}{l}0.052 \\
0.082 \\
0.133\end{array}$ & $\begin{array}{l}45.3 \\
59.7 \\
67.2\end{array}$ \\
\hline 5. & $\begin{array}{l}\text { Minimum............... } \\
\text { Average................... } \\
\text { Maximum............. }\end{array}$ & $\begin{array}{l}28 \\
32.5 \\
38\end{array}$ & $\begin{array}{l}15 \\
16.5 \\
20\end{array}$ & $\begin{array}{l}1.65 \\
2.95 \\
4.67\end{array}$ & $\begin{array}{l}1.24 \\
1.46 \\
1.59\end{array}$ & $\begin{array}{l}0.039 \\
0.064 \\
0.080\end{array}$ & $\begin{array}{l}55.7 \\
59.5 \\
63.3\end{array}$ \\
\hline 6. & 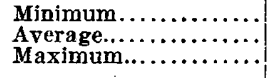 & $\begin{array}{l}27 \\
32.4 \\
37\end{array}$ & $\begin{array}{l}10 \\
15.8 \\
19\end{array}$ & $\begin{array}{l}1.73 \\
2.33 \\
3.30\end{array}$ & $\begin{array}{l}1.14 \\
1.37 \\
1.75\end{array}$ & $\begin{array}{l}0.056 \\
0.078 \\
0.101\end{array}$ & $\begin{array}{l}41.1 \\
58.1 \\
66.2\end{array}$ \\
\hline 7. & 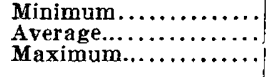 & $\begin{array}{l}25 \\
31.8 \\
39\end{array}$ & $\begin{array}{l}13 \\
15.8 \\
18\end{array}$ & $\begin{array}{l}1.50 \\
2.02 \\
2.52\end{array}$ & $\begin{array}{l}1.25 \\
1.44 \\
1.68\end{array}$ & $\begin{array}{l}0.058 \\
0.077 \\
0.123\end{array}$ & $\begin{array}{l}55.7 \\
62.0 \\
74.8\end{array}$ \\
\hline 8. & $\begin{array}{l}\text { Minimum. } \\
\text { Average......................... } \\
\text { Maximum.............. }\end{array}$ & $\begin{array}{l}23 \\
31.8 \\
38\end{array}$ & $\begin{array}{l}12 \\
16.4 \\
20\end{array}$ & $\begin{array}{l}1.57 \\
2.08 \\
2.50\end{array}$ & $\begin{array}{l}0.99 \\
1.21 \\
1.42\end{array}$ & $\begin{array}{l}0.062 \\
0.085 \\
0.024\end{array}$ & $\begin{array}{l}46.2 \\
57.4 \\
62.4\end{array}$ \\
\hline 9. & 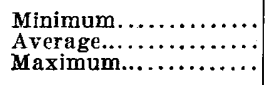 & $\begin{array}{l}31 \\
31.7 \\
32.4\end{array}$ & $\begin{array}{l}15 \\
15.5 \\
16\end{array}$ & $\begin{array}{l}1.95 \\
1.97 \\
2.00\end{array}$ & $\begin{array}{l}1.30 \\
1.34 \\
1.39\end{array}$ & $\begin{array}{l}0.071 \\
0.078 \\
0.086\end{array}$ & $\begin{array}{l}57.6 \\
60.1 \\
61.4\end{array}$ \\
\hline 10. & 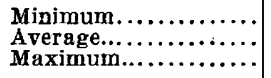 & $\begin{array}{l}23 \\
28.7 \\
37\end{array}$ & $\begin{array}{l}12 \\
14 \\
15\end{array}$ & $\begin{array}{l}1.22 \\
2.15 \\
3.12\end{array}$ & $\begin{array}{l}1.06 \\
1.16 \\
1.35\end{array}$ & $\begin{array}{l}0.066 \\
0.077 \\
0.085\end{array}$ & $\begin{array}{l}56.7 \\
59.5 \\
64.3\end{array}$ \\
\hline 11. & $\begin{array}{l}\text { Minimum............... } \\
\text { Average................. } \\
\text { Maximum............ }\end{array}$ & $\begin{array}{l}26 \\
30.8 \\
35\end{array}$ & $\begin{array}{l}13 \\
15.2 \\
17\end{array}$ & $\begin{array}{l}1.42 \\
1.84 \\
2.38\end{array}$ & $\begin{array}{l}1.11 \\
1.28 \\
1.50\end{array}$ & $\begin{array}{l}0.092 \\
0.099 \\
0.112\end{array}$ & $\begin{array}{l}55.7 \\
60.5 \\
66.2\end{array}$ \\
\hline 12. & 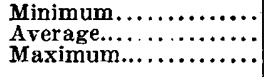 & $\begin{array}{l}24.1 \\
27.6 \\
31\end{array}$ & $\begin{array}{l}12.7 \\
13.6 \\
15\end{array}$ & $\begin{array}{l}1.45 \\
1.72 \\
2.06\end{array}$ & $\begin{array}{l}1.00 \\
1.11 \\
1.29\end{array}$ & $\begin{array}{l}0.072 \\
0.083 \\
0.097\end{array}$ & $\begin{array}{l}50.7 \\
58.3 \\
63.6\end{array}$ \\
\hline
\end{tabular}

Nonprotein nitrogen, urea, sugar and uric acid by Folin method; carbon dioxid, Van Slyke; creatinin by Folin and Wu method.

In comparing our results with the observations made by Schlititz and Pettibone ${ }^{13}$ we find our figures to be somewhat higher than theirs. The figures of Sedgwick et al (ibid.) are higher than ours except the

13. Schlutz and Pettibone: Am. J. Dis. Child. 10:206 (Sept.) 1916. 
urea nitrogen which falls below our findings. Our blood sugar findings are somewhat lower than those of Sedgwick et al., although comparative curves would be almost parallel. Our only explanation of the low sugar findings in this series is that the infants were breast fed and received no supplementary food except water. They were on four hour feedings and the estimations were taken just before nursing.

The graphic curves which are appended show a very definite drop in the nonprotein nitrogen, urea and creatinin during the first few days and show a definite rise in the sugar and carbon dioxid curve. There are comparatively few estimations on creatinin during the first few weeks. Our curves show very definitely that during this period there is a high body catabolism as the creatinin is only of endogenous origin.

\section{CALCIUM}

Howland and Marriott ${ }^{14}$ have shown that the calcium values in blood for infants are essentially those found in the adult. They examined placental blood and blood from six normal infants. They did not state the age of these infants but we presume that none of them were new-born. In their comparison they found very little variation of the calcium content between the placental blood (from 10.7 to $11 \mathrm{mg}$. per hundred c.c. blood), normal adult blood (from 9.2 to $11.2 \mathrm{mg}$. per hundred c.c blood), and normal infant blood (from 10.8 to $11.5 \mathrm{mg}$. per hundred c.c. blood).

In a recent study by Jones and $\mathrm{Nye}^{15}$ from our laboratories, the distribution of calcium and phosphoric acid in the blood of normal children was found to average in whole blood $9.4 \mathrm{mg}$. per hundred c.c. ; corpuscles, 8.7 ; plasma, 10 . So far as we are aware, no data have been published on the distribution of the calcium in the blood of the new-born.

Table 10 gives the results of sixty-eight determinations on twentytwo infants ranging in age from 1 to 12 days.

The technic followed for these determinations was the same as that described by Jones and Nye, except that 3 c.c. corpuscles were laked with an equal volume of distilled water and 5 c.c. of this was added to 20 c.c. trichloracetic acid instead of 5 c.c. of a one to three dilution. This was found to be necessary on account of the low calcium content of the corpuscles of the new-born. The blood was collected about four hours after the last feeding, from 15 to 20 c.c. being taken from the longitudinal sinus. From one to five determinations were made on each of twenty-two infants, twelve boys and ten girls. The first sample of blood was taken as soon after birth as possible, usually within twelve hours, and at intervals of three or four days thereafter as long as the infant was in the hospital.

14. Howland and Marriott: Tr. Am. Ped. Soc. 28:202, 1916.

15. Jones and Nye: J. Biol. Chem. 47:321 (July) 1921. 


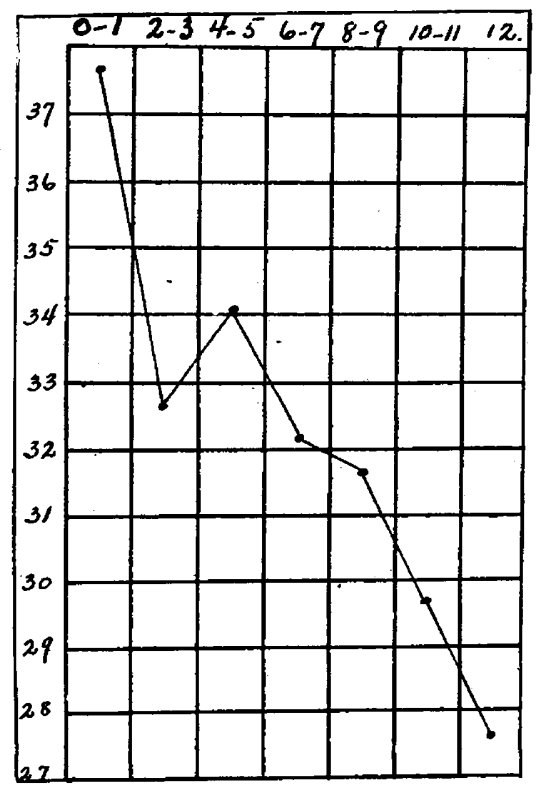

Fig. 8.-Nonprotein nitrogen, mg. per hundred c.c.

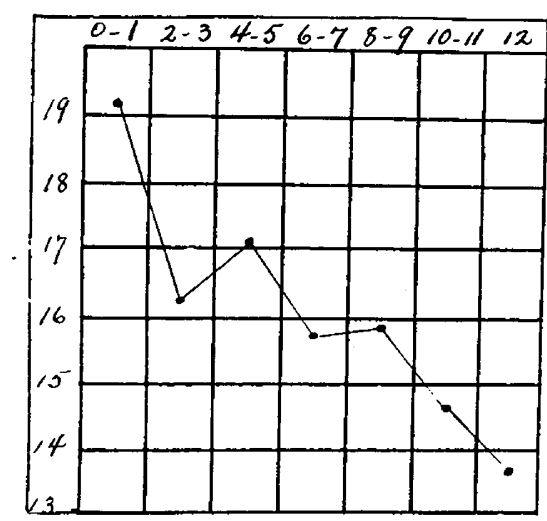

Fig. 9.-Urea nitrogen, mg. per hundred c.c. 


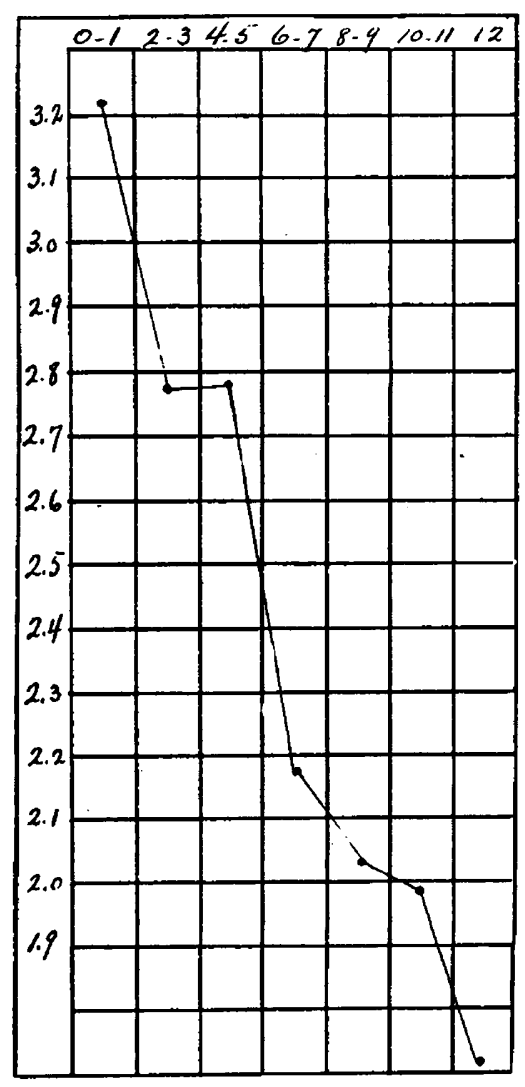

Fig. 10.-Uric acid, mg. per hundred c.c.

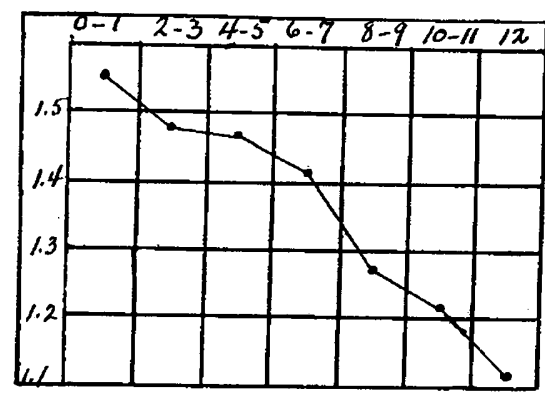

Fig. 11.-Creatinin, mg. per hundred c.c. 
An examination of Table 10 shows that the average calcium content of the plasma is higher in the new-born than in older children. This is in agreement with the findings of Meiggs, Blatherwick and Cary ${ }^{16}$ who showed that in heifers the calcium content of the blood plasma

Table 10.-A. Calcium Content of the Blood of Normal Infants From Birth to 12 DaYs of AGE*

\begin{tabular}{|c|c|c|c|c|c|c|}
\hline \multirow{2}{*}{$\operatorname{Sex}$} & \multirow{2}{*}{$\begin{array}{l}\text { Age, } \\
\text { Days }\end{array}$} & \multirow{2}{*}{$\begin{array}{c}\text { No. of } \\
\text { Determi- } \\
\text { nation } \\
\text { Included } \\
\text { in }\end{array}$} & \multirow{2}{*}{$\begin{array}{c}\text { Average } \\
\text { Hemato- } \\
\text { crit } \\
\text { Reading, } \\
\text { per Cent. }\end{array}$} & \multicolumn{3}{|c|}{$\begin{array}{c}\text { Average Oalcium Values } \\
\text { per } 100 \text { C.c. }\end{array}$} \\
\hline & & & & $\begin{array}{c}\text { Whole } \\
\text { Blood, } \\
\text { Mg. }\end{array}$ & $\begin{array}{l}\text { Corpus- } \\
\text { cles, } \\
\text { Mg. }\end{array}$ & $\begin{array}{l}\text { Plasma, } \\
\text { Mg. }\end{array}$ \\
\hline 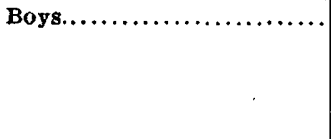 & $\begin{array}{c}0-2 \\
2-4 \\
4-6 \\
6-8 \\
8-10 \\
10-12\end{array}$ & $\begin{array}{l}5 \\
6 \\
6 \\
6 \\
6 \\
6\end{array}$ & $\begin{array}{l}55.1 \\
50.5 \\
49.1 \\
45.7 \\
47.2 \\
40.8\end{array}$ & $\begin{array}{l}8.7 \\
8.9 \\
8.8 \\
9.0 \\
8.9 \\
9.4\end{array}$ & $\begin{array}{l}\mathbf{5 . 8} \\
\mathbf{5 . 4} \\
\mathbf{5 . 4} \\
\mathbf{5 . 2} \\
\mathbf{5 . 1} \\
\mathbf{5 . 0}\end{array}$ & $\begin{array}{l}12.1 \\
12.3 \\
12.3 \\
12.3 \\
12.3 \\
12.3\end{array}$ \\
\hline Average................ & $0-12$ & 35 & 48.6 & 9.0 & 5.3 & 12.3 \\
\hline Girls................... & $\begin{array}{c}0-2 \\
2-4 \\
4-6 \\
6-8 \\
8-10 \\
10-12\end{array}$ & $\begin{array}{l}6 \\
6 \\
5 \\
5 \\
6 \\
5\end{array}$ & $\begin{array}{l}54.8 \\
49.2 \\
49.0 \\
45.7 \\
43.9 \\
42.8\end{array}$ & $\begin{array}{l}8.2 \\
8.5 \\
8.6 \\
8.8 \\
8.9 \\
9.1\end{array}$ & $\begin{array}{l}4.9 \\
4.9 \\
4.7 \\
4.7 \\
4.5 \\
4.7\end{array}$ & $\begin{array}{l}12.2 \\
12.0 \\
12.2 \\
12.3 \\
12.1 \\
12.5\end{array}$ \\
\hline Average................ & $0-12$ & 33 & 47.4 & 8.7 & 4.7 & 12.2 \\
\hline Boys and girls.............. & $\begin{array}{c}0-2 \\
2-4 \\
4-6 \\
6-8 \\
8-10 \\
10-12\end{array}$ & $\begin{array}{l}11 \\
12 \\
11 \\
11 \\
12 \\
11\end{array}$ & $\begin{array}{l}55.0 \\
49.9 \\
49.1 \\
45.7 \\
45.5 \\
41.9\end{array}$ & $\begin{array}{l}8.4 \\
8.7 \\
8.7 \\
8.9 \\
8.9 \\
9.3\end{array}$ & $\begin{array}{l}5.4 \\
5.2 \\
5.1 \\
5.0 \\
4.8 \\
4.9\end{array}$ & $\begin{array}{l}12.2 \\
12.2 \\
12.3 \\
12.3 \\
12.3 \\
12.4\end{array}$ \\
\hline Average................. & $0-12$ & 68 & 48.0 & 8.8 & 5.0 & 12.3 \\
\hline
\end{tabular}

B. Averages and Variations in the Calcium Content of the Blood of Normal Infants Ranging in Age from 4 Hours to 12 Days, and of Normal Children from 4 WeEks to 14 Years *

\begin{tabular}{|c|c|c|c|c|}
\hline & \multicolumn{3}{|c|}{ Calcium per 100 C.c. } & \multirow{2}{*}{$\begin{array}{l}\text { Red Blood } \\
\text { Cells, } \\
\text { per Cent. }\end{array}$} \\
\hline & $\begin{array}{l}\text { Whole Blood, } \\
\text { Mg. }\end{array}$ & $\begin{array}{l}\text { Corpuseles, } \\
\text { Mg. }\end{array}$ & $\begin{array}{l}\text { "isma, } \\
\text { Kg. }\end{array}$ & \\
\hline 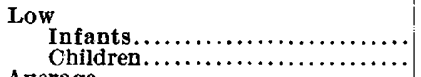 & $\begin{array}{l}8.1 \\
5.6\end{array}$ & $\begin{array}{l}4.2 \\
5.2\end{array}$ & $\begin{array}{r}\mathbf{1 1 . 4} \\
\mathbf{5 . 5}\end{array}$ & $\begin{array}{l}37.1 \\
30.1\end{array}$ \\
\hline $\begin{array}{l}\text { Average } \\
\quad \text { Infants. } \\
\quad \text { Children } \ldots \ldots \ldots \ldots \ldots \ldots \ldots \ldots \ldots \ldots \ldots \ldots \ldots \ldots \ldots \ldots \ldots \ldots \ldots \ldots\end{array}$ & $\begin{array}{l}8.8 \\
9.4\end{array}$ & $\begin{array}{l}5.0 \\
8.7\end{array}$ & $\begin{array}{l}12.3 \\
10.0\end{array}$ & $\begin{array}{l}48.0 \\
38.2\end{array}$ \\
\hline 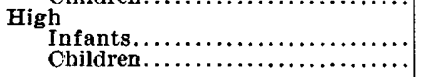 & $\begin{array}{l}10.3 \\
12.4\end{array}$ & $\begin{array}{r}6.9 \\
12.0\end{array}$ & $\begin{array}{l}13.2 \\
12.4\end{array}$ & $\begin{array}{r}64.5 \\
44.0\end{array}$ \\
\hline
\end{tabular}

* Analyses made by Martha R. Jones, Ph.D.

is highest at birth and tends to become lower with advance in age up to six months. It is interesting to note the constancy of the plasma volumes throughout the series, each determination varying less than $0.4 \mathrm{mg}$. per hundred c.c. from the general average $(12.3 \mathrm{mg}$. per

16. Meiggs, Blatherwick and Cary: J. Biol. Chem. 37:1, 1919. 


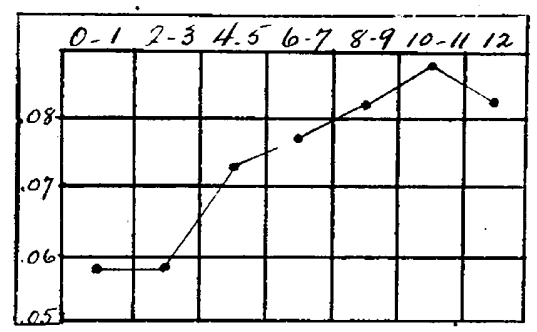

Fig. 12.-Sugar per cent. per hundred c.c.

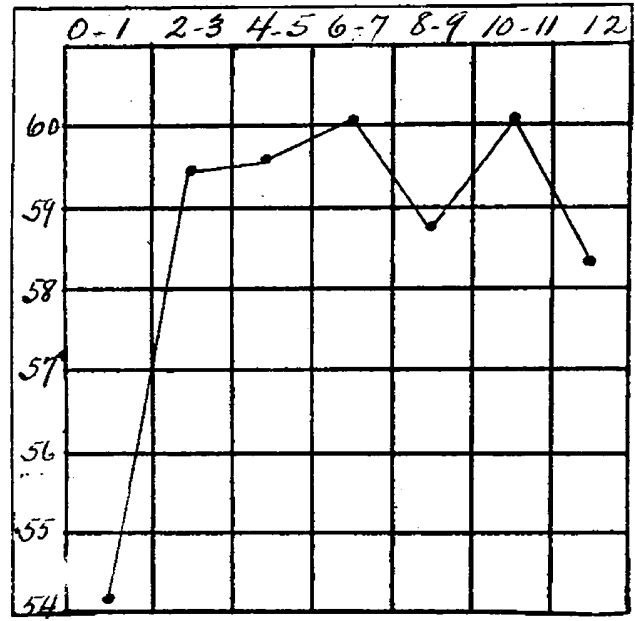

Fig. 13.-Carbon dioxid volume per cent. per hundred c.c. 
100 c.c.). Apparently in man the drop in the plasma content does not occur during the first twelve days of life. The value for whole blood ( $8.8 \mathrm{mg}$. per hundred c.c.) is slightly less than that (9.5 mg.) reported by Brown, MacLachlan and Simpson ${ }^{17}$ in normal infants under 1 year of age while the average content of corpuscles ( $5 \mathrm{mg}$.) is markedly less than that $(8.7 \mathrm{mg}$.) found by Jones and Nye in older children.

In general, the corpuscle values tend to decrease slightly during the first few days. The difference, however, in the majority of cases was well within the limits of experimental error and too much emphasis should not be laid on it. On the other hand, there is a tendency for the whole blood values to increase. This is what one would expect with relatively constant values for plasma and corpuscles and a marked decrease in the percentage of cells. The calcium values in the new-born tend to run higher in boys than girls, as was pointed out by Jones and Nye in the case of older children.

These calcium estimations go to show very clearly that in the blood of the new-born, calcium is rarely at fault in any problem related to hemorrhage of the new-born, except in those cases of obstructive jaundice in which case the calcium is bound with the bile salts and is, therefore, unavailable for entering into the process of coagulation.

\section{COAGULATION}

Many methods for estimating coagulation time have been developed, but all these methods so far have employed blood derived from superficial puncture. Rodda ${ }^{18}$ has reviewed various methods for estimating coagulation time. He has proposed a very useful clinical method for the estimation of blood obtained from punctures in which "all factors, such as depth and site of puncture, size and sequence of the drops, temperature, air currents and the effect of foreign bodies in contact with the blood were duly considered." However, any method which uses a puncture wound must of necessity have certain inherent errors. As has been pointed out by Lee and White ${ }^{19}$ and Lee and Vincent, ${ }^{20}$ the only accurate methods for determining coagulation time are those in which the blood is obtained by venipuncture. The advantages of obtaining the blood directly from a vein or from the longitudinal sinus, as we carried it out, are that there is no contact with tissue or skin. It has been shown by these authors that blood drawn from superficial punctures clots in varying time depending on the depth of the puncture wound.

17. Brown, MacLachlan and Simpson: Am. J. Dis. Child. 19:413, 1920.

18. Rodda: Am. J. Dis. Child. 19:269 (April) 1920.

19. Lee and White: Am. J. M. Sc. 145:495 (Apri1) 1913.

20. Lee and Vincent: Arch. Int. Med. 13:398 (Apri1) 1914. 


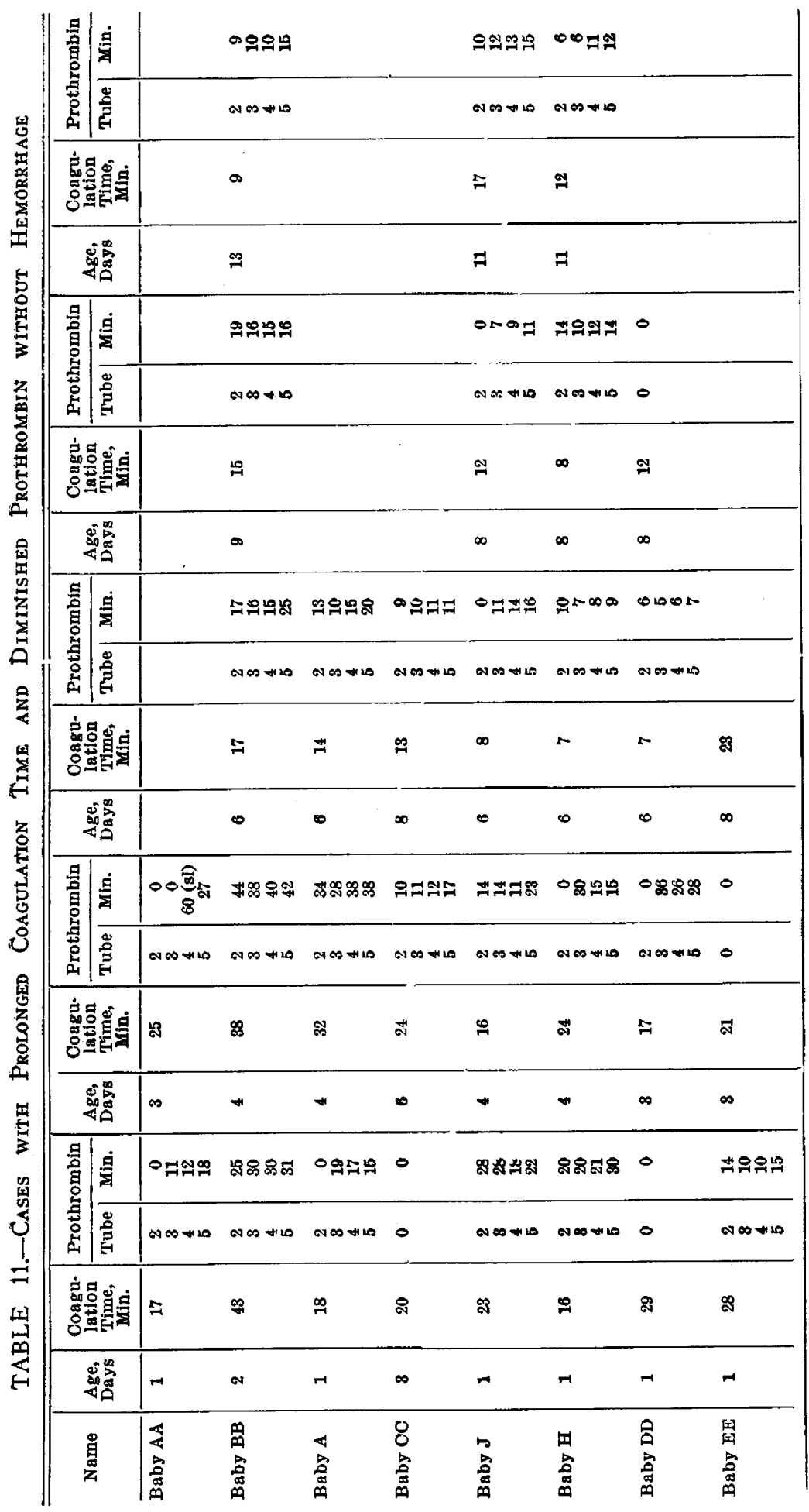




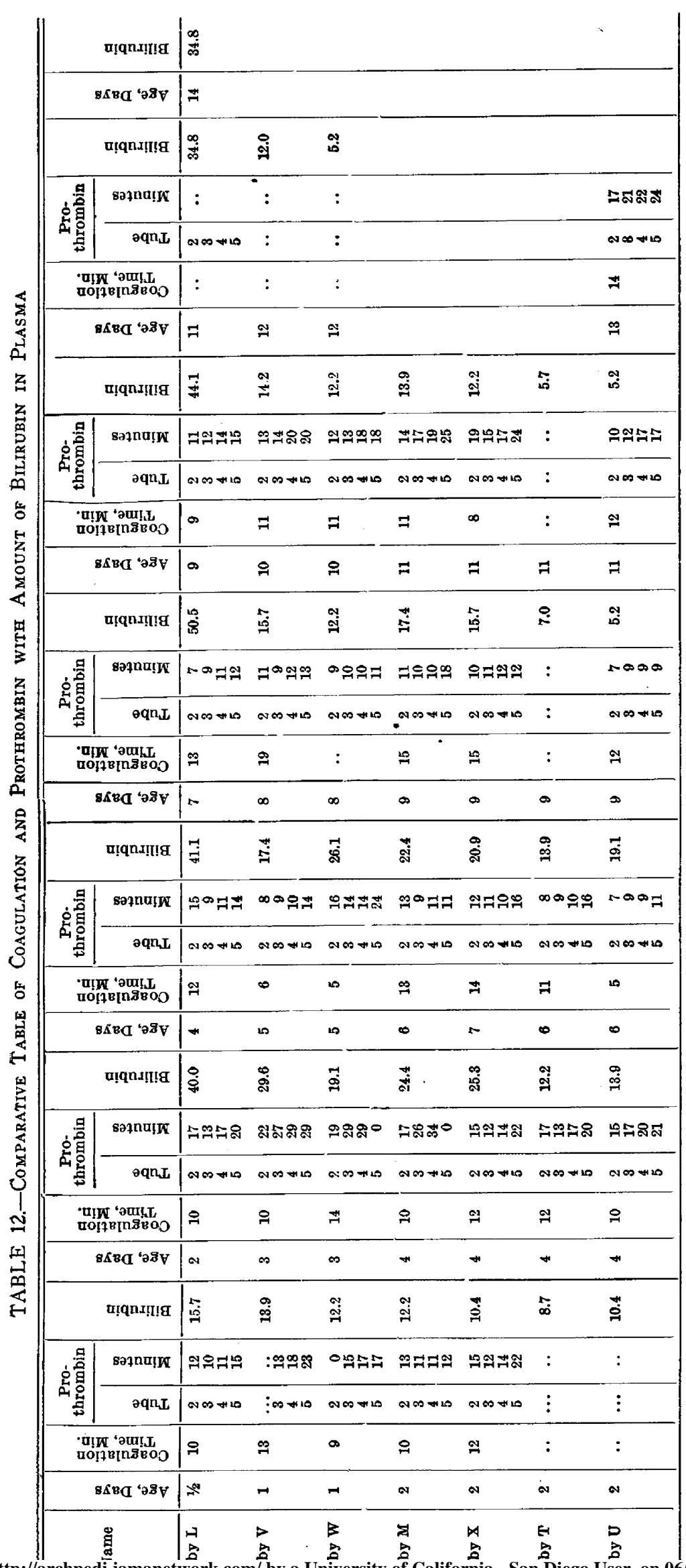




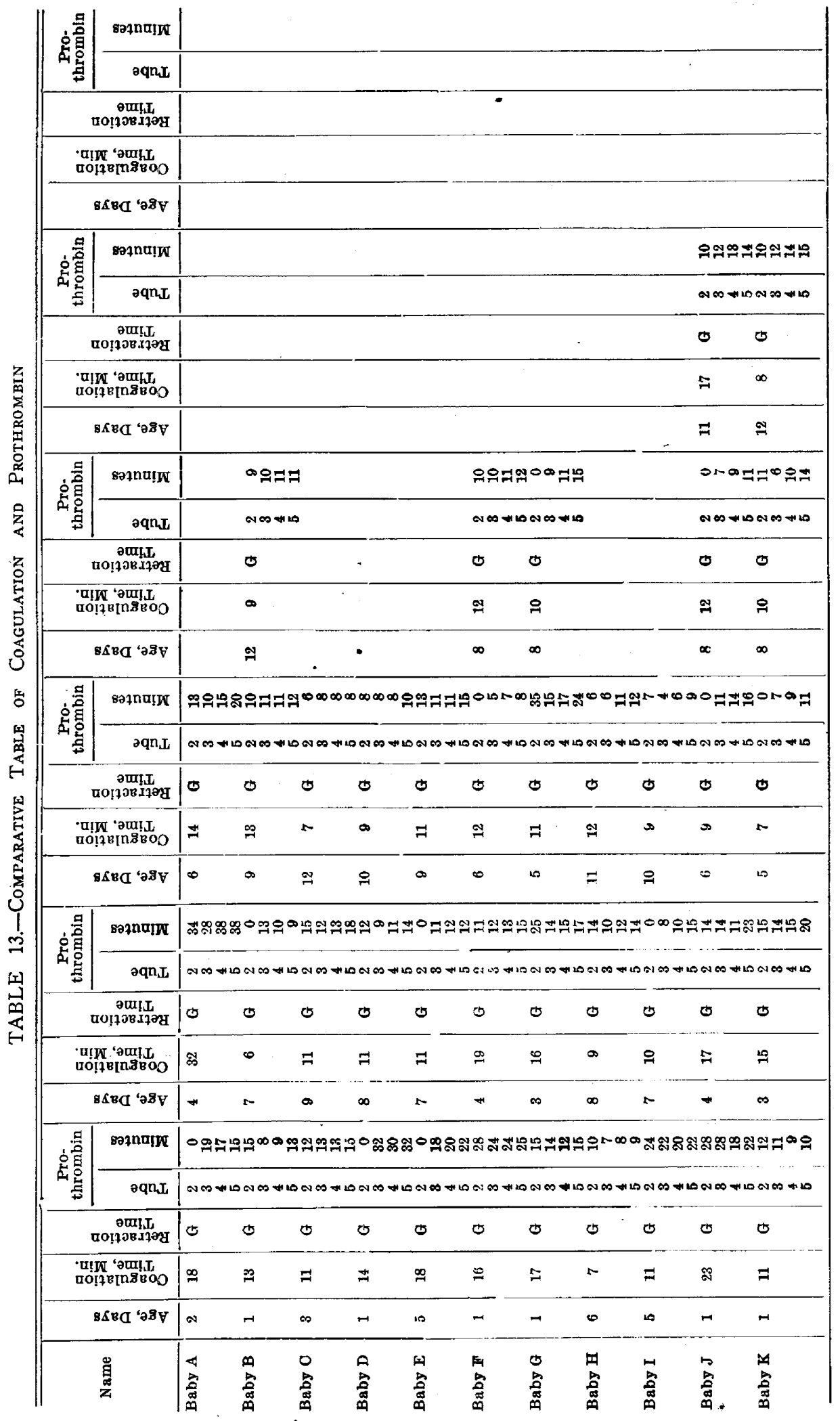

Downloaded From: http://archpedi.jamanetwork.com/ by a University of California - San Diego User on 06/07/2015 


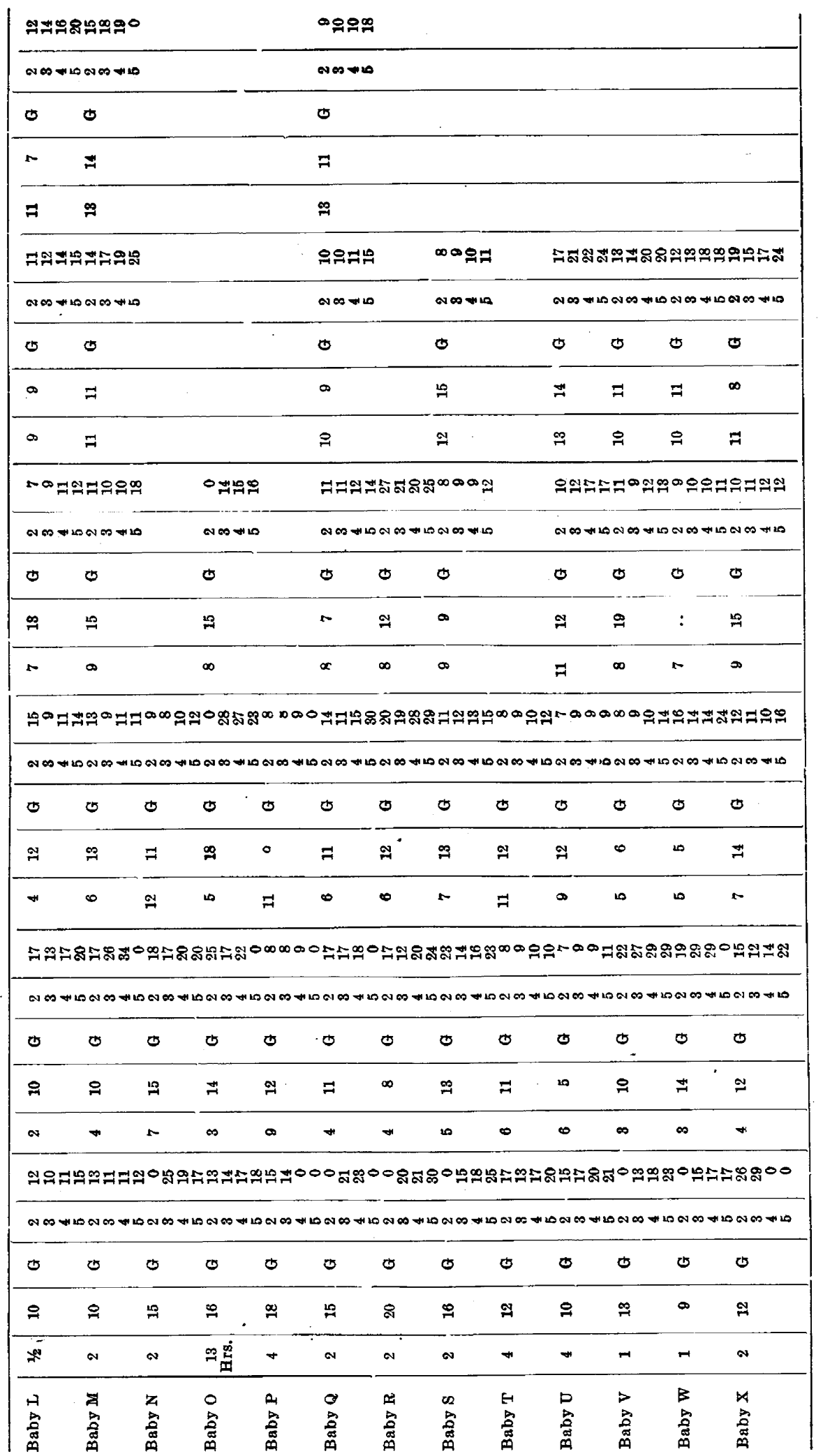

Downloaded From: http://archpedi.jamanetwork.com/ by a University of California - San Diego User on 06/07/2015 
The method used by us was to obtain blood from the longitudinal sinus with an all glass luer syringe which had been sterilized carefully, washed out with physiologic solution of sodium chlorid and then coated with sterile oil (liquid petrolatum). The blood was immediately delivered in 2 c.c. quantities into test tubes measuring $21 \mathrm{~mm}$. in diameter which had been previously cleansed in bichromate and dried with alcohol and ether. The tubes were allowed to stand for five minutes before the first test was made, as any coagulation which occurred in less time than this was found to be due to lack of technic, difficulty in getting the blood from the sinus, introduction of air bubbles, etc. After a five minute period the tubes were rotated every thirty seconds and the coagulation time was determined at the point when the tubes could be inverted without the clot slipping. This was taken as the end point.

Our results are shown in Figures 14 and 15.

This shows very clearly that during the first four days there is a definite prolongation in the coagulation time. This is a very important observation, as we feel that it shows clearly that during these first few days there is a definite and fairly constant condition in the blood of the new-born which favors the so-called hemorrhagic condition of the newborn. As has been shown by various studies in isolated cases, the hemorrhagic condition of the new-born may be divided into several classes. Whipple has shown in certain cases of hemorrhage of the new-born that the prothrombin element is a causative factor. We have made the same observation in the study of a case of hemorrhagic disease of the new-born by Gelston. ${ }^{21}$ Whipple has also shown in certain cases of liver disturbance that the fibrogen factor may be at fault, and in cases of obstructive jaundice of the new-born the calcium factor is undoubtedly partly at fault. In cases of sepsis, the antithrombin factor has been shown by Whipple to be involved.

However, we wish to emphasize the fact that the blood of the newborn normally has a prolonged coagulation time, whether hemorrhage appears or not. The appearance of hemorrhage, we believe, depends on whether this factor is exaggerated or not. We have found the coagulation time prolonged as long as twenty, thirty and forty minutes without the appearance of any hemorrhage or increase in bleeding time. This average (bleeding time) is from one and one-half to three minutes in all cases.

As has already been pointed out, the calcium content of the blood of the new-born is greater than that of older infants. We have also pointed out that the platelets are not diminished. During this same period of prolonged coagulation time the serum bilirubin curve is also increased, but it does not seem to affect the coagulation time in cases of marked jaundice. Table 12 bears out this statement. These are

21. Gelston: Am. J. Dis. Child. 22: 351 (Oct.) 1921. 
representative cases with marked increase in coagulation or decrease in prothrombin element as compared with our normal curves.

We have investigated the prothrombin factor and the following curves, we believe, prove that during the period in which the coagulation time is prolonged the prothrombin element is definitely diminished. The curves in all the tubes to which calcium was added, varying in amount from 2 to 5 drops according to Howell's method of recalcifying oxalated blood by the addition of the optimum amount of calcium

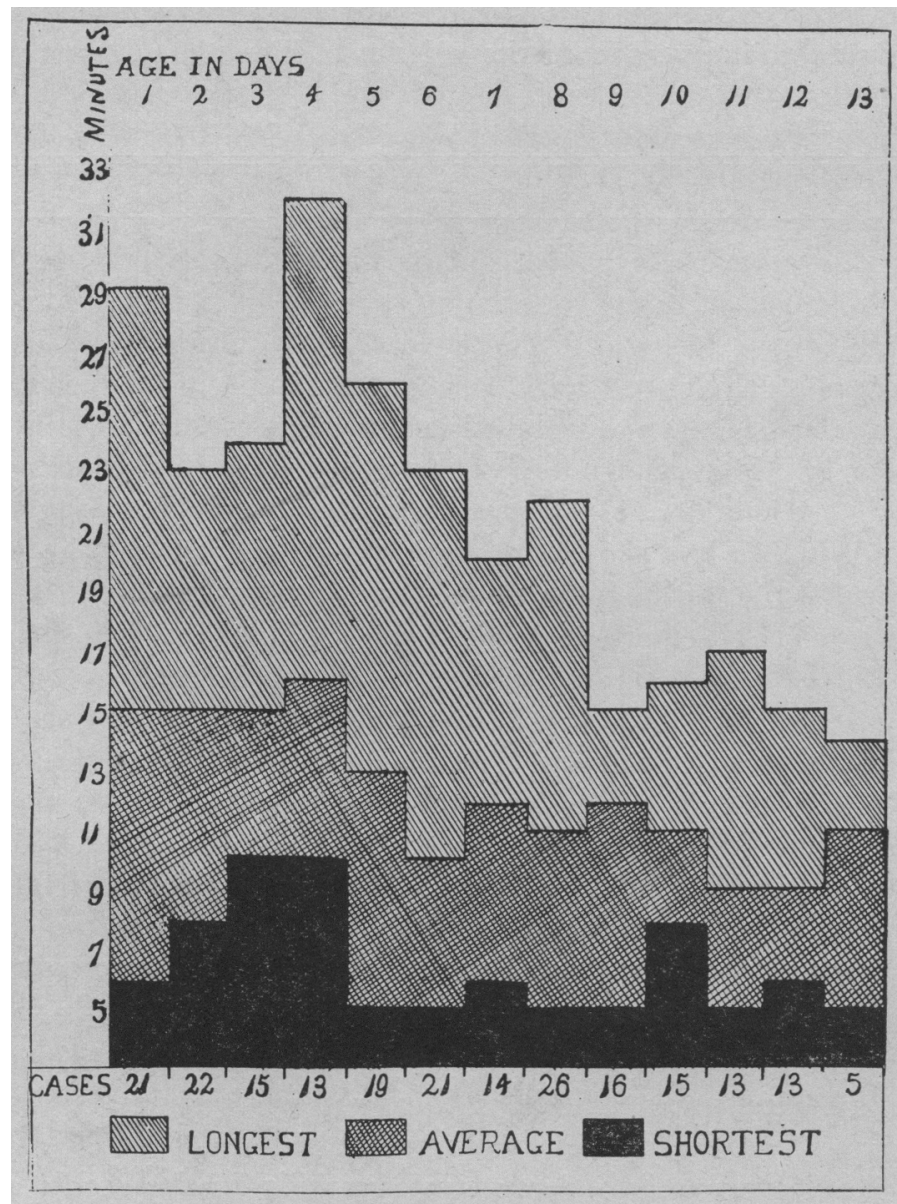

Fig. 14.-Coagulation.

chlorid, show a diminution of the prothrombin element during the first four or five days. After this time the prothrombin factor apparently reaches normal levels though it may be delayed in certain cases for several days longer. We have attempted to show that this is due to a qualitative defect in the platelets as was shown by Minot and Lee ${ }^{22}$ to exist in the case of hemophilia.

22. Minot and Lee: Arch. Int. Med. 18:474 (Oct.) 1916. 
Table 14, we believe, shows that the same qualitative defect exists in the platelets of the new-born during these first few days.

The blood of the new-born did not show any defect in retractility of the clot and there was no fibrinolysis. This is exactly the condition which exists in hemophilia. After the blood clots in hemophilia the retraction of the clot is normal and there is no fibrinolysis. We feel confident, therefore, that the factor involved in the ordinary case of hemorrhage of the new-born is due to diminution in the prothrombin element which is mainly derived from the platelets and the defect is essentially a qualitative one of the platelets. The platelets apparently

TABLE 14.-Difference in Prothrombin and Platelets on Various Days

\begin{tabular}{|c|c|c|c|c|c|c|c|c|c|c|c|}
\hline \multirow{2}{*}{$\frac{\text { Name }}{\text { Baby FF }}$} & \multirow{2}{*}{$\frac{\text { Age }}{2}$} & \multicolumn{2}{|c|}{ Clear } & \multicolumn{2}{|c|}{ Very Olear } & \multicolumn{2}{|c|}{4 Drops } & \multicolumn{2}{|c|}{6 Drops } & \multicolumn{2}{|c|}{8 Drops } \\
\hline & & $\begin{array}{l}2 \\
3 \\
4 \\
5\end{array}$ & $\begin{array}{r}17 \\
10 \\
9 \\
9\end{array}$ & $\begin{array}{l}2 \\
3 \\
4 \\
5\end{array}$ & $\begin{array}{r}0 \\
0 \\
30 \\
18\end{array}$ & $\begin{array}{l}4 \\
5\end{array}$ & $\begin{array}{l}10 \\
20\end{array}$ & $\begin{array}{l}4 \\
5\end{array}$ & $\begin{array}{l}20 \\
24\end{array}$ & $\begin{array}{l}4 \\
5\end{array}$ & $\begin{array}{r}17 \\
0\end{array}$ \\
\hline Baby GG & 4 & $\begin{array}{l}2 \\
3 \\
4 \\
5\end{array}$ & $\begin{array}{r}0 \\
0 \\
34 \\
20\end{array}$ & $\begin{array}{l}2 \\
3 \\
4 \\
5\end{array}$ & $\begin{array}{r}0 \\
50 \\
45\end{array}$ & $\begin{array}{l}4 \\
5\end{array}$ & $\begin{array}{l}25 \\
23\end{array}$ & $\begin{array}{l}4 \\
5\end{array}$ & $\begin{array}{l}21 \\
20\end{array}$ & $\begin{array}{l}4 \\
5\end{array}$ & $\begin{array}{l}15 \\
15\end{array}$ \\
\hline Baby $\mathrm{HH}$ & 4 & $\begin{array}{l}2 \\
3 \\
4 \\
5\end{array}$ & $\begin{array}{l}\ddot{ } \\
\because \\
\because .\end{array}$ & $\begin{array}{l}2 \\
3 \\
4 \\
5\end{array}$ & $\begin{array}{c}0 \\
0 \\
0 \\
1 \mathbf{h r} .\end{array}$ & $\begin{array}{l}4 \\
5\end{array}$ & $\begin{array}{l}27 \\
23\end{array}$ & $\begin{array}{l}4 \\
5\end{array}$ & $\begin{array}{r}0 \\
23\end{array}$ & $\begin{array}{l}4 \\
5\end{array}$ & $\begin{array}{r}0 \\
20\end{array}$ \\
\hline Baby II & 7 & $\begin{array}{l}2 \\
3 \\
4 \\
5\end{array}$ & $\begin{array}{r}17 \\
10 \\
9 \\
9\end{array}$ & $\begin{array}{l}\mathbf{2} \\
3 \\
4 \\
\mathbf{4}\end{array}$ & $\begin{array}{l}22 \\
18 \\
22\end{array}$ & $\begin{array}{l}4 \\
5\end{array}$ & $\begin{array}{l}9 \\
6\end{array}$ & $\begin{array}{l}4 \\
5 \\
5\end{array}$ & $\begin{array}{l}8 \\
8\end{array}$ & $\begin{array}{l}4 \\
5\end{array}$ & $\begin{array}{l}7 \\
8\end{array}$ \\
\hline Baby JJ & 9 & $\begin{array}{l}2 \\
3 \\
4 \\
5\end{array}$ & $\begin{array}{r}14 \\
11 \\
9 \\
9\end{array}$ & $\begin{array}{l}2 \\
3 \\
4 \\
5\end{array}$ & $\begin{array}{l}16 \\
16 \\
12 \\
15\end{array}$ & $\begin{array}{l}4 \\
5\end{array}$ & $\begin{array}{l}6 \\
6\end{array}$ & $\begin{array}{l}4 \\
5\end{array}$ & $\begin{array}{l}8 \\
6\end{array}$ & $\begin{array}{l}4 \\
5\end{array}$ & $\begin{array}{l}6 \\
6\end{array}$ \\
\hline Baby KK & 10 & $\begin{array}{l}\mathbf{2} \\
\mathbf{3} \\
\mathbf{4} \\
\mathbf{5}\end{array}$ & $\begin{array}{r}10 \\
10 \\
10 \\
8\end{array}$ & $\begin{array}{l}2 \\
3 \\
4 \\
5\end{array}$ & $\begin{array}{l}18 \\
17 \\
15 \\
17\end{array}$ & $\begin{array}{l}4 \\
5\end{array}$ & $\begin{array}{l}\mathbf{5} \\
\mathbf{5}\end{array}$ & $\begin{array}{l}4 \\
5\end{array}$ & $\begin{array}{l}\mathbf{5} \\
\mathbf{5}\end{array}$ & $\begin{array}{l}4 \\
5\end{array}$ & $\begin{array}{l}5 \\
6\end{array}$ \\
\hline Baby LL & 10 & $\cdots$ & $\because$ & $\begin{array}{l}2 \\
3 \\
4 \\
5\end{array}$ & $\begin{array}{r}0 \\
16 \\
18 \\
20\end{array}$ & $\begin{array}{l}3 \\
4\end{array}$ & $\begin{array}{l}8 \\
8\end{array}$ & $\begin{array}{l}3 \\
4\end{array}$ & $\begin{array}{l}8 \\
8\end{array}$ & $\begin{array}{l}3 \\
4\end{array}$ & $\begin{array}{l}7 \\
8\end{array}$ \\
\hline
\end{tabular}

obtain their normal prothrombin element very rapidly after birth. It is during the first three or four days that most cases of hemorrhage of the new-born occur and it is during the same period that the platelets are defective in their prothrombin element.

We have attempted to demonstrate urobilin in the stools of the new-born. Our technic was as follows: Soft paper diapers were used in the collection of stools and the entire mass from which all of the uncontaminated paper had been removed was dropped immediately after - being passed into a specimen jar containing about 150 c.c. of a dilute hydrochloric acid solution (1 c.c. concentrated hydrochloric acid solution to 100 c.c. distilled water). The stools were collected in two day periods, the dilute acid being used to prevent bacterial decomposi- 
tion. The entire mass (paper and stool) was macerated in the original jar with a spatula and pestle and the liquid portion strained through a Büchner funnel. The residue was then ground in a mortar until of even consistency and added to the liquid that had been strained off. After thorough mixing, the liquid portion was again strained through the funnel into a graduate, as much as possible being expressed from the paper pulp. The volume of pulp was then determined, and one-half of the amount calculated as stool mixture was added to that measured in the graduate. In order to approximate the amount of water necessary to make a pulp of like consistency, a measured amount of water was added to some of the paper diapers and treated as in the stool mixture. The excess of water was expressed and the volume required to make a known amount of pulp calculated. It was found that approximately 50 c.c. of water were used in making 100 c.c. of pulp.

The method for the determination of urobilin and urobilinogen was that described by Wilbur and Addis. ${ }^{23}$ So far we have been unable to show the presence of any urobilin in the stools of new-born infants during the first twelve days of life, nor have we so far been able to demonstrate urobilin in stools of infants up to ten weeks of age, although in older children it is easy to demonstrate its presence. This still leaves open the question of what becomes of the red blood cells which diminished so rapidly during these first few days of life. We hope by further studies to be able to answer some of the questions which so far have not been satisfactorily solved by these and other studies on the new-born.

\section{BILE PIGMENT IN THE PLASMA}

The problem of icterus neonatorum is one which has received a great deal of attention, but so far there are many conflicting theories regarding its cause. At this time we do not intend to go into the discussion of the various phases but simply to report the method of testing for bile pigment in blood plasma which we believe is more accurate from a qualitative as well as quantitative standpoint than any other method thus far advanced for routine study.

Method.-The sample of freshly drawn blood is mixed at once with a sufficient amount of oxalate and centrifuged at high speed for thirty minutes. This removes the platelets, and since the blood was drawn before feeding there is little clouding from fat. The resulting supernatant plasma is usually clear, with varying shades of red to brown from the various chromatic elements present. Three c.c. of the plasma or serum are withdrawn in a calibrated pipet and transferred drop by drop into a 25 c.c. volumetric flask containing a little less than 22 c.c. of the acid alcohol standard solution (this solution is made up to 30 c.c. of concentrated hydrochloric acid with sufficient 95 per cent. alcohol to make 2,000 c.c.). After delivering the sample of plasma, the volumetric flask is filled to the 25 c.c. level with the standard solution. On standing (from twelve to twenty-four hours), an emerald green color

23. Wilbur and Addis: Arch. Int. Med. 13:235 (March) 1914. 
develops which reaches its maximum intensity by twenty-four hours. From this place in the procedure the method follows that of Hooper and Whipple." The solution is filtrated and read in the Hellige's colorimeter against a standard wedge made up of gelatin, copper sulphate and India ink. The standard wedge is the same as is used in connection with the pigment analysis of the bile in the routine bile fistula work at the Hooper Foundation. This wedge has been standardized against pure bilirubin (Kaulbaum), bilirubin from gallstones and crystalline bilirubin from dog's bile. A table for the values in milligrams of bilirubin corresponding to the colorimeter readings allows a quick determination of pigment in the samples of plasma.

In arriving at the above routine method, several difficulties were apparent. It was certain that the blood would not contain the same amount of pigment as the bile and it was possible that the precipitation of the protein might occlude considerable pigment. Accordingly, the proportion of plasma to acid alcohol could not be the same as the proportion of bile to acid alcohol. It was found after repeated trials that 3 c.c. of plasma in 25 c.c. of acid alcohol developed sufficient color to be read against the bile pigment standard wedge and yet did not require the withdrawal of too large amounts of blood. This proportion insures thorough precipitation of the proteins and sufficient filtrate to make several estimations. In fact, where only 1 c.c. of plasma is obtainable, the proportion of 1 c.c. in 10 c.c. of acid alcohol will give approximate results. For accuracy, the 3 c.c. sample is preferable.

The development of the color can, of course, be hastened by heating or by adding nitric acid. Furthermore, just as with the bile, the pigment, after forty-eight hours, approaches the blue field which is indicative of oxidation past biliverdin to the bilicyanin. As a routine, the color was developed at room temperature while exposed to the light of the laboratory.

Although this color reaction is specific for bile pigments it was not certain that when applied to the blood the method was sufficiently accurate for quantitative analysis. However, it was found that if plasma from normal controls (serum from normal adults) which gave only the white protein precipitate with no color development, was used to dilute icteric plasmas the diluted specimens could be estimated with the proportional amount of pigment. Furthermore, when known amounts of bile containing estimated quantities of bile pigment were added to either icteric plasmas or non-icteric plasmas the resulting mixtures when estimated gave the theoretical calculation well within the delicacy of the method. The bile used was both human bile from operative cholecystostomy cases and dog bile from the bile fistula animals in the Hooper Laboratory.

Table 15 shows the accuracy of the method in the recovery of known amounts of pigment.

Although there are numerous qualitative tests for bilirubin, few of these are obtainable for quantitative methods. In most cases, the tests 
apply to the bile or urine. A method for quantitative estimation of bile pigment in the blood, while much to be desired, has not as yet to our knowledge been perfected for routine study.

Further, the quantitative estimation of substances by the colorimetric method always presents a great many difficulties and at best involves considerable experimental error. This would seem particularly true concerning the estimation of bilirubin in the blood where, as is known, there are present not only the related hemoglobin derivatives but also the lipochromes.

Table 15.-Bile Pigment in Plasma

\begin{tabular}{|c|c|c|c|}
\hline Sample & Proportion & $\begin{array}{c}\text { Calculated } \\
\text { Reading }\end{array}$ & $\begin{array}{c}\text { Theoretical } \\
\text { Reading }\end{array}$ \\
\hline 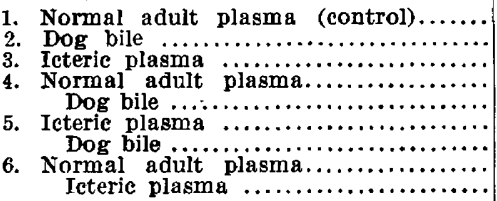 & $\begin{array}{l}3.0 \text { c.c. in } 25 \text { c.c. } \text { St. } \\
0.3 \text { c.c. in } 21 \text { c.c. St. } \\
3.0 \text { c.c. in } 25 \text { c.e. St. } \\
2.9 \text { c.c. in } 25 \text { c.c. St. } \\
0.1 \text { c.c. in } 25 \text { c.c. St. } \\
2.9 \text { c.c. in } 25 \text { c.c. St. } \\
0.1 \text { c.c. in } 25 \text { c.c. St. } \\
1.0 \text { e.c. in } 25 \text { c.c. St. } \\
2.0 \text { c.c. in } 25 \text { c.c. St. }\end{array}$ & $\begin{array}{l}\text { No color } \\
30 \\
20 \\
10 \\
31 \\
15\end{array}$ & $\begin{array}{c}\text { No color } \\
30 \\
20 \\
10 \\
30\end{array}$ \\
\hline
\end{tabular}

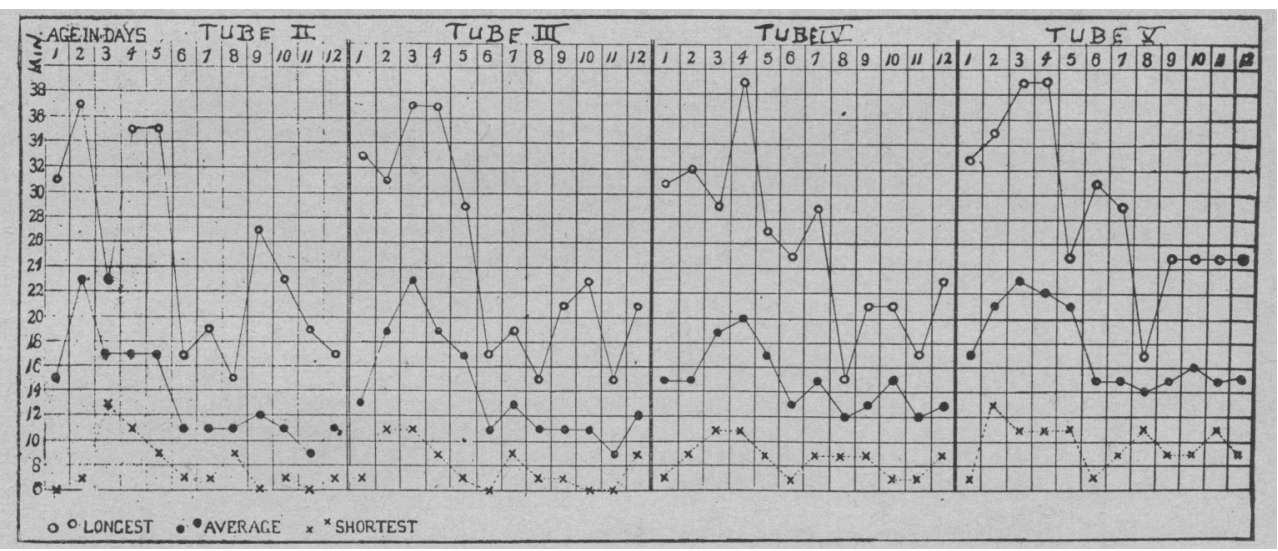

Fig. 15.-Prothrombin.

It is not within the scope of this paper to present at this time a review of our knowledge of the relation of methemoglobin, hematin, bilirubin, urobilin and urochrome. Since the work of Virchow, ${ }^{25}$ Stadleman, ${ }^{26}$ Küster, ${ }^{27}$ and more recently Whipple and Hooper, ${ }^{28}$ the identity of hematoidin and bilirubin has been generally accepted. The distinction between hematinaemia and true icterus must also be borne in mind. As concerns the lipochromes (xanthophylls and carotins), the

25. Virchow: Arch. f. Path. Anat. 1:379, 1847.

26. Stadleman: Der Icterus, Stuttgart, 1891, pp. 3-45.

27. Küster: Ztschr. f. Physiol. Chem. 59.

28. Whipple and Hooper: J. Exper. Med. 17:612, 1913. 
work of Palmer ${ }^{29}$ and Hess and Meyers ${ }^{30}$ has shown that exogenous pigments are present which may produce a pseudo-icteric condition with both skin and serum manifestations.

Obviously any method which seeks to estimate the concentration of bile pigment, i.e., bilirubin in the blood, with any degree of accuracy must be specific. Numerous authors and investigators have sought to estimate the quantity of bile pigment by a comparison or dilution of the colored serum, free, of course, from blood, etc. In this country Blankenhorn ${ }^{31}$ has made clinical studies based on this "tintometer method" in which the amount is estimated by the dilution necessary to reach the color just able to be discerned. Mülengracht ${ }^{32}$ and his co-workers have used a similar method though somewhat more detailed in which 1 c.c. of the citrated serum is placed in a standard test tube and diluted with 0.9 per cent. sodium chlorid solution until the same tint as the standard solution, which is a 1 to 10,000 bichromate solution, is obtained. This is supposed to represent normal serum. From our present knowledge of the varieties of endogenous and exogenous chromatic elements which may occur normally and pathologically in the blood, it is obvious that these methods are open to criticism since they cannot be used to discriminate the nature of the pigment which they seek to estimate.

Ehrlich's diazo reaction was first studied in relation to the bile pigments by Pröscher. ${ }^{33}$ In 1913, van der Bergh and Snapper ${ }^{84}$ applied this method to the quantitative estimation of bilirubin in the blood. Since the introduction of this method and its numerous modifications a great many experimental clinical observations have been made and the test has assumed an important diagnostic use. The test has also shown differences occurring in the sera of various animals. Of recent date, Bauer and Spiegel ${ }^{35}$ have studied the fluctuations not only in obstructive jaundice and febrile states but also under the influence of various drugs. Fiegle and Querner ${ }^{36}$ have found the normal content increased in a wide variety of pathological conditions. These observations have not been constant in the findings by other investigators.

In comparing the diazo method with that used in our series of observations a sharp distinction is found. Thus normal adult plasmas which gave nothing but a clear white protein precipitate with the acid alcohol standard used in our determinations, nevertheless

29. Palmer: J. Biol. Chem. 17:211, 1914.

30. Hess and Meyers: J. A. M. A. 73:1743 (Dec. 6) 1919.

31. Blankenhorn: Arch. Int. Med. 21:282 (March) 1918.

32. Mülengracht: Acta Med. Scandinav, 53:827 (Jan. 14) 1921.

33. Präscher: Ztschr. f. Physiol. Chem. 29:411, 1900.

34. van der Bergh and Snapper: Deutsch. Arch. f. klin. Med. 110:540, 1913.

35. Bauer and Spiegel: Deutsch. Arch. f. klin. Med. 129:17, 1919.

36. Fiegle and Querner: Ztschr. f. Exper. Med. 9:153, 1919. 
registered a positive diazo reaction, which according to v.d. Bergh, Fiegle and others, represents the normal threshold of bilirubin in human serum. Those icteric plasmas which develop the green color by our method also gave an intense red color by the diazo. This would appear at first to indicate the diazo reaction to be more delicate; but, as other workers have shown, the diazo reaction may be produced by substances other than the bile pigments. ${ }^{37}$ In other words, the reaction is based on the chemical group which may be found in a variety of substances. Ehrlich himself at first applied the method for the estimation of unknown groups of substances in the urine. The sharp distinction between the two methods above discussed indicates, we believe, the lack of specificity in the diazo reaction. It is not within the scope of this paper to discuss the conflicting views of the relation of urobilin, urobilinogen and urochrome, but we believe the overlapping of the several tests (Russo, Weisz and Diazo) further indicates the nonspecificity of the diazo reaction. The explanation of the direct and indirect diazo reaction again indicates a variety of substances which will react with Ehrlich's diazo solution.

The characteristic green color which develops on oxidation of bilirubin to biliverdin is perhaps the most specific color reaction for the bile pigments. This has been the basis for most of the well known qualitative tests such as Hammersten's and Gmelin's. It has also furnished the basis for numerous quantitative methods for determining bile pigment in both bile and blood.

Ivar Bang ${ }^{38}$ made an excellent series of observations, especially on the icterus of the new-born in which he depended on the development of the blue-green ring at the line of contact between the serum and the oxidizing agent which consisted of 300 parts of nitric acid with 0.06 of sodium nitrate (Gmelin-Sunde technic). The speed of the development of the color and the intensity of the color gave a rough estimate of the concentration of bile pigment. A similar method was adapted by Gilbert. ${ }^{39}$

Fourchet ${ }^{40}$ precipitated the proteins with chloroform and estimated the concentration of the pigment in the oxidation to the characteristic green color. Perchlorid of iron was used to hasten oxidation. This method was designed generally for qualitative work, but as Fourchet has shown, lends itself for the quantitative estimations.

Hooper and Whipple, who have made a most thorough study of the bile pigment in the bile, advocate a precipitation method for the estimation of the pigment in serum and body fluid.

37. Herter: J. Biol. Chem. 1:251, 1905; 4:403, 1908.

38. Bang: Hospitalstid. 8:637, 1915.

39. Gilbert: Presse méd. 14:201, 1906.

40. Fourchet: Compt. rend. Soc. Biol. 80:826, 1917. 
The serum is made alkali with saturated solution of sodium bicarbonate and mixed with a 10 per cent. solution of calcium chlorid, giving a voluminous precipitate containing the bile pigments. The precipitate is thrown down and washed repeatedly with distilled water by the use of the centrifuge. The precipitate is finally dissolved in a measured amount of the nitrohydrochloric acid alcohol solution and allowed to stand at room temperature over night. The pigments are then estimated by the colorimeter.

Hedenius ${ }^{41}$ had previously shown that qualitative bilirubin could be detected in the blood by precipitating the protein with alcohol, filtrating and acidifying the filtrate with hydrochloric acid. It is, therefore, possible that a shorter method than the precipitation method could be found for quantitative estimation. Such a method is used in the estimation of the pigment in the bile itself.

On experimentation it was found that the clear icteric plasmas presented no factors, either in the protein or the chromatic elements, which prevented the direct estimation of the pigments without precipitation. Furthermore, instead of first precipitating the proteins, as Hedenius advocated, the two processes of precipitation of the protein and oxidation of the pigment could be carried out in one.

Finally, as regards the more detailed precipitation process, it has been our observation that not only does this method involve a greater experimental error on account of the added steps, but also the calcium chlorid fails to precipitate all the pigments present, for after adding the calcium chlorid in large amounts the filtrate still gives positive tests for the presence of pigment.

Yllpö ${ }^{42}$ used a spectrophotometric method. Undoubtedly this is one of the most reliable methods, not only for qualitative determination of the bile pigment but also for quantitative analysis. In studying the distinction of the various chromatic elements in the blood it is of infinite value. However, for a simple method, it cannot be reduced for quick routine work.

We have examined ninety cases by the method we have proposed for the examination of bilirubin in the plasma. Of these cases, seventytwo showed a positive reaction. During the course of this investigation we also noted as carefully as it was possible to do so the appearance of clinical icterus. If anyone has attempted to do this in a cosmopolitan clinic, such as we have, they will realize the difficulty of being absolutely sure of slight cases of icterus. During the period we were carrying on these observations there were often infants of as many as eight or nine different nationalities in the nursery. There is no difficulty in determining marked icterus, but we do not feel absolutely certain of the exact proportion of clinical icterus. Table 16 details the number of cases in which we were able to say that clinical icterus was present as compared with the finding of bilirubin in the plasma.

41. Hedenius: Upsala Läkaref. Förh. 29:541, 1893.

42. Yllpö: Ztschr. f. Kinderh. 9:208, 1913. 
This shows very definitely that toward the third day the findings in the plasma and clinical icterus correspond fairly closely. The difference is not to be taken too exactly; as already noted, it is difficult often to determine slight degrees of clinical icterus. From the third day on, the plasma and bilirubin findings and clinical icterus correspond fairly well.

Figure 16 shows graphically these same findings.

Table 16.-Clinical Icterus and Bilirubin in Plasma of New-Born

\begin{tabular}{|c|c|c|c|}
\hline \multirow[t]{3}{*}{90 Cases } & Examined, 72 Positiv & $\begin{array}{l}\text { n. } 26 \text { Cord } \\
\text { sitive }\end{array}$ & \multirow{3}{*}{$\begin{array}{l}\text { Examined, } \\
\text { Clinical Ieterus }\end{array}$} \\
\hline & & Plasma & \\
\hline & Positive & Negative & \\
\hline $\begin{array}{c}\text { (0-23 hours) } \\
1 \\
2 \\
\mathbf{3} \\
4 \\
5 \\
6 \\
7\end{array}$ & $\begin{array}{r}6 \\
25 \\
30 \\
42 \\
39 \\
30 \\
28 \\
26\end{array}$ & $\begin{array}{r}1 \\
3 \\
4 \\
2 \\
6 \\
10 \\
16 \\
18\end{array}$ & $\begin{array}{r}2 \\
6 \\
20 \\
35 \\
33 \\
25 \\
23 \\
21\end{array}$ \\
\hline
\end{tabular}

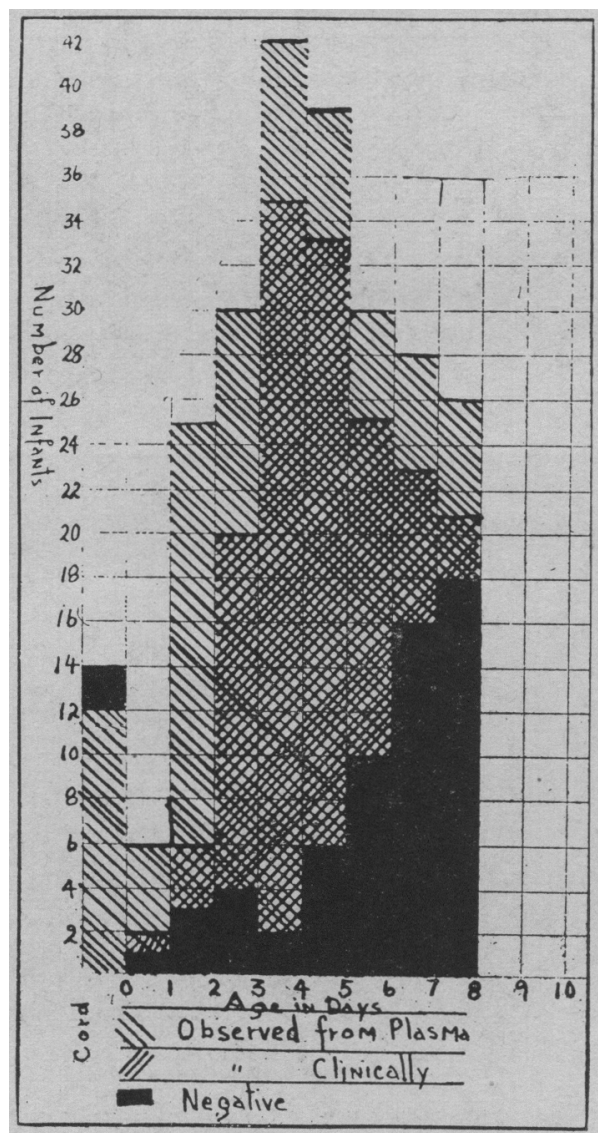

Fig. 16.-Findings in blood plasma of new-born with icterus. 
Figure 17 shows an average curve of the seventy-two positive cases with bilirubin in the plasma and a typical curve of an individual case which ran above the average of the seventy-two. It might be noted here that the cases which ran a low value of bilirubin in their plasma

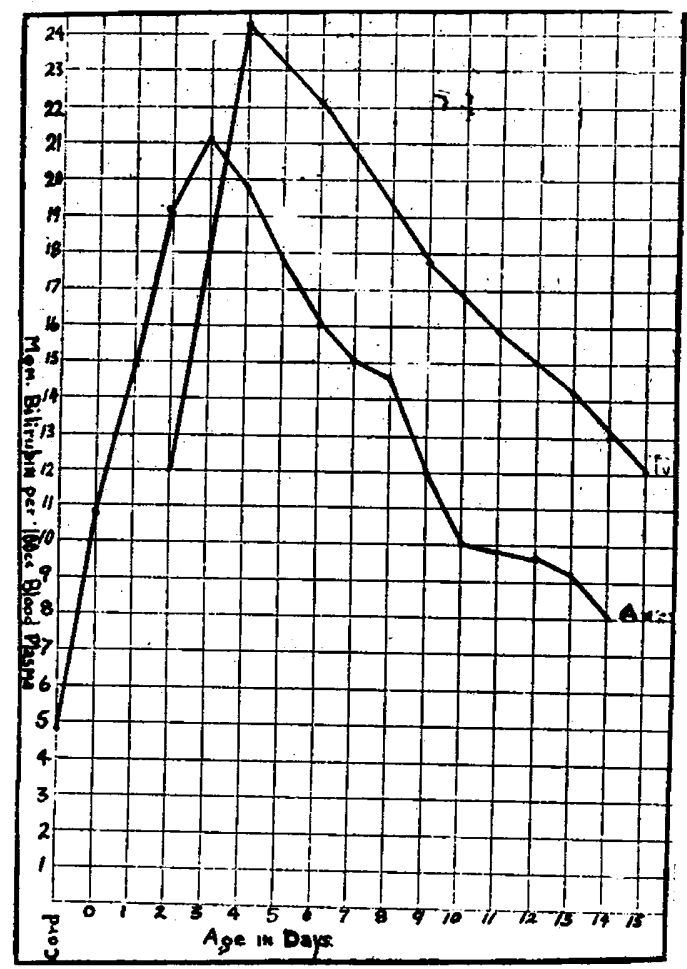

Fig. 17.-Average curve of seventy-two positive cases, and typical curve of individual case above average.

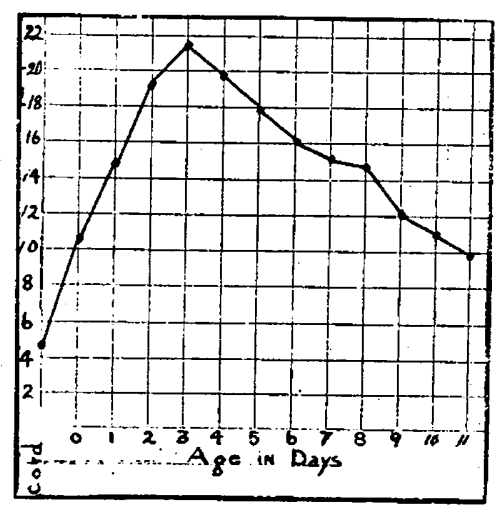

Fig. 18.-Average curve in seventy-two cases in mg. bilirubin per hundred c.c. blood plasma. 
reached the maximum earlier than the high value cases which reached their maximum somewhat later than the average curve, i.e., the average curve reaches its maximum on the third day. Low value cases often reach their maximum before this day where high value cases reach it sometime after the third day and continue with high values for a longer period.

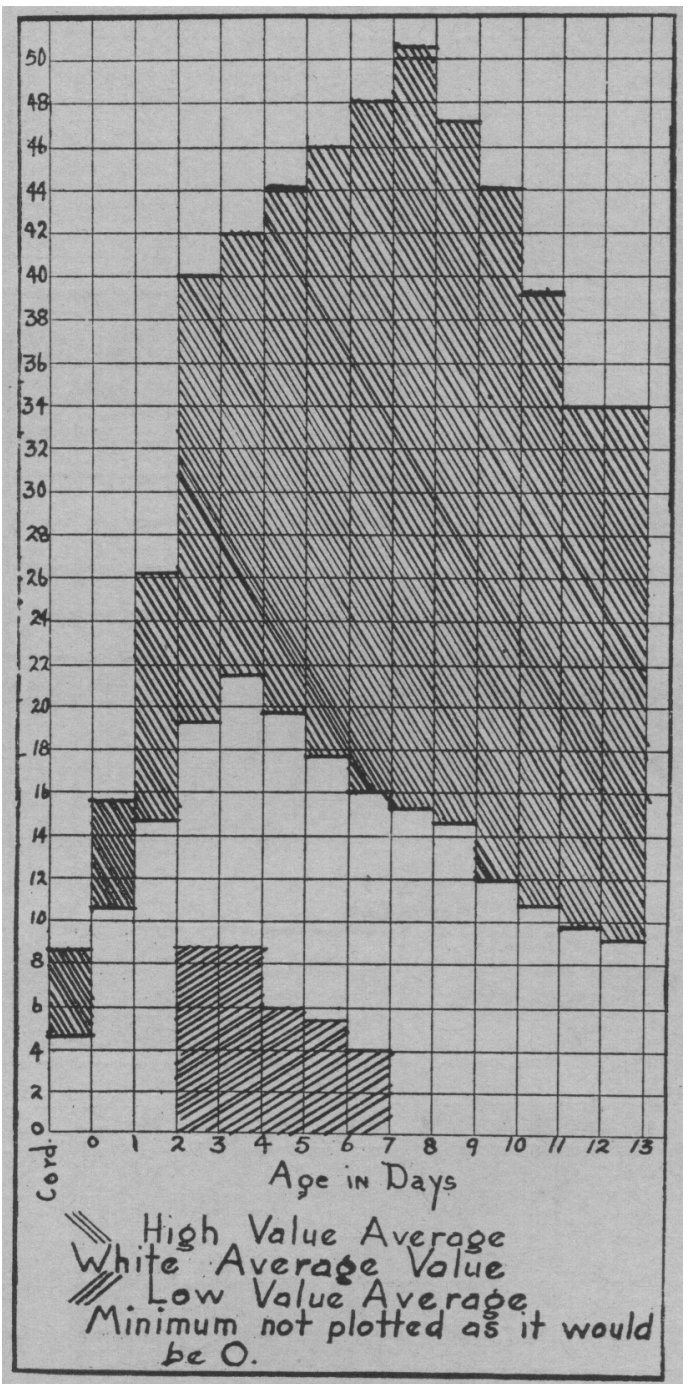

Fig. 19.- Maximum, average and low value readings in $\mathrm{mg}$. bilirubin per hundred c.c. blood plasma.

Figure 18 shows a simple average curve of the seventy-two cases drawn on a somewhat different scale.

Figure 19 shows the maximum, average and low value readings in mg. bilirubin per hundred c.c. blood plasma. 
TABLE 17.-Ten Cases in Which at Least Four Observations on Bilirubin in Blood Plasma Were Made

\begin{tabular}{|c|c|c|c|c|c|c|c|c|c|c|c|c|c|c|}
\hline \multirow{3}{*}{ Name } & \multicolumn{14}{|c|}{ Mg. Bilirubin per 100 . C.c. Blood Plasma } \\
\hline & \multicolumn{14}{|c|}{ Age in Days } \\
\hline & Cord & 0 & 1 & 2 & 3 & 4 & 5 & 6 & 7 & 8 & 9 & 10 & 11 & 12 \\
\hline $\begin{array}{r}\text { 1. Mallove... } \\
\text { 2. Simpson.. } \\
\text { 3. Hudekott. } \\
\text { 4. Bride...... } \\
\text { 5. Duarts.... } \\
\text { 6. Sarris I... } \\
\text { 7. Sarris II... } \\
\text { 8. Monez..... } \\
\text { 9. Nicholsen.. } \\
\text { 10. Palmeri... }\end{array}$ & $\begin{array}{l}4.7 \\
\cdots \\
\dddot{4.7} \\
\ldots \\
\cdots \\
\cdots \\
\cdots \\
\cdots\end{array}$ & $\begin{array}{l}17.4 \\
\ldots . . \\
\ldots . . \\
\ldots \ldots . \\
\ldots \ldots . \\
\ldots \ldots . \\
\ldots .0\end{array}$ & $\begin{array}{l}\ldots . .7 \\
19.1 \\
\ldots . . \\
\ldots . . \\
\ldots . . \\
12.2 \\
13.9 \\
\ldots . .\end{array}$ & $\begin{array}{r}\ldots . . \\
\ldots . . \\
26.1 \\
19.1 \\
8.7 \\
10.4 \\
\ldots . . \\
\ldots . .\end{array}$ & $\begin{array}{l}31.3 \\
27.8 \\
27.0 \\
\ldots \ldots . \\
\ldots \ldots \\
\ldots \ldots . \\
19 . \\
29.1 \\
19.1\end{array}$ & $\begin{array}{l}\ldots . . \\
\ldots . . \\
\ldots .0 \\
\ldots .0 \\
12.2 \\
13.9 \\
\ldots . . \\
\ldots .\end{array}$ & $\begin{array}{l}20.9 \\
22.6 \\
\ldots \ldots \\
20.9 \\
\ldots \ldots . \\
\dddot{20.1} \\
17.4 \\
31.3\end{array}$ & $\begin{array}{l}\ldots . . \\
20.9 \\
\ldots \ldots \\
13.9 \\
19.1 \\
\ldots \ldots \\
\ldots \ldots\end{array}$ & $\begin{array}{l}8.7 \\
\ldots . \\
\ldots . . \\
20.9 \\
19.4 \\
\ldots . . \\
\ldots . . \\
\ldots \ldots \\
26.1\end{array}$ & $\begin{array}{l}12.2 \\
19.7 \\
\ldots \ldots . \\
\ldots \ldots \\
\ldots . . \\
12.2 \\
15.7 \\
\ldots . .\end{array}$ & $\begin{array}{r}\cdots . . \\
20.9 \\
19.1 \\
7.0 \\
5.2 \\
\cdots \cdots \\
\cdots \cdots\end{array}$ & $\begin{array}{c}\ldots . \\
\ldots . \\
\dddot{12.2} \\
14.2 \\
19.7\end{array}$ & $\begin{array}{r}17.4 \\
5.7 \\
5.2 \\
\ldots \ldots \\
\ldots \ldots \\
\ldots .\end{array}$ & $\begin{array}{r}5.2 \\
12.0 \\
17.8\end{array}$ \\
\hline
\end{tabular}

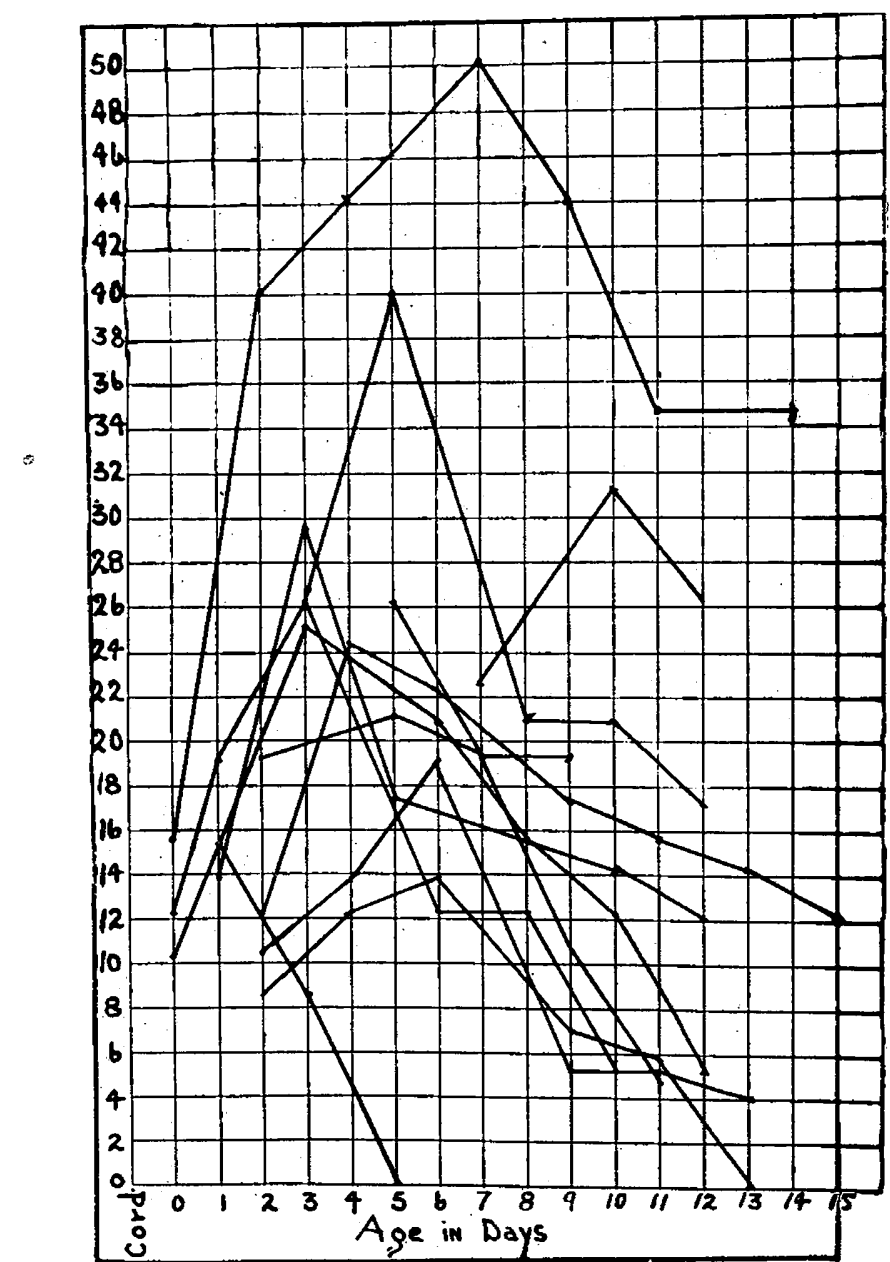

Fig. 20.-Curves of twelve cases showing variations in bilirubin in blood plasma, mg. per hundred c.c. blood plasma. 
Figure 20 shows plotted curves of twelve individual cases showing the variations in bilirubin in blood plasma.

In Table 17 are shown ten cases in which at least four observations on bilirubin in blood plasma were made. This table shows very conclusively the value of this method not only as a qualitative but also as a quantitative method for estimating bilirubin in blood plasma. The + marks in the individual squares represent the day on which icterus was clinically noted. Infants Nos. 6 and 7 were twins and it can be seen how closely the bilirubin ran throughout their whole period of observation. Two cases are shown in which cord blood was also examined. In Case 1 it is very evident that in the circulating blood of the new-born there is a very much larger percentage of bilirubin than in the cord blood. In this case the blood plasma from the infant was obtained within a few hours after delivery.

At the present time we do not feel in a position to discuss the all important question as to what becomes of the red blood cells, but we do feel that this method for testing bilirubin gives us a much better means of attacking this problem. We are now engaged in carrying out a combined study of bilirubin in blood, stools and urine, together with other studies on this problem. We hope in the near future to be able to report on some of these findings. 